\title{
Phospholipids in Salt Stress Response
}

\author{
Xiuli Han ${ }^{1}$ and Yongqing Yang ${ }^{2, *}$ \\ 1 School of Life Sciences and Medicine, Shandong University of Technology, Zibo 255049, China; \\ hanhxl@sdut.edu.cn \\ 2 State Key Laboratory of Plant Physiology and Biochemistry, College of Biological Sciences, \\ China Agricultural University, Beijing 100193, China \\ * Correspondence: yangyongqing@cau.edu.cn; Tel./Fax: +86-10-62732030
}

Citation: Han, X.; Yang, Y

Phospholipids in Salt Stress

Response. Plants 2021, 10, 2204

https://doi.org/10.3390/

plants10102204

Academic Editors: Ok Ran Lee and Yu-Jin Kim

Received: 5 September 2021

Accepted: 13 October 2021

Published: 17 October 2021

Publisher's Note: MDPI stays neutral with regard to jurisdictional claims in published maps and institutional affiliations.

\begin{abstract}
High salinity threatens crop production by harming plants and interfering with their development. Plant cells respond to salt stress in various ways, all of which involve multiple components such as proteins, peptides, lipids, sugars, and phytohormones. Phospholipids, important components of bio-membranes, are small amphoteric molecular compounds. These have attracted significant attention in recent years due to the regulatory effect they have on cellular activity. Over the past few decades, genetic and biochemical analyses have partly revealed that phospholipids regulate salt stress response by participating in salt stress signal transduction. In this review, we summarize the generation and metabolism of phospholipid phosphatidic acid (PA), phosphoinositides (PIs), phosphatidylserine (PS), phosphatidylcholine (PC), phosphatidylethanolamine (PE) and phosphatidylglycerol (PG), as well as the regulatory role each phospholipid plays in the salt stress response. We also discuss the possible regulatory role based on how they act during other cellular activities.
\end{abstract}

Keywords: phospholipids; salt stress; phosphatidic acid; phosphoinositide; phosphatidylserine; phosphatidylcholine; phosphatidylethanolamine; phosphatidylglycerol

\section{Introduction}

Salt (sodium chloride) accumulated in irrigated soil is toxic to plant growth and development, and approximately $40 \%$ of irrigated land worldwide is affected by increased salt stress [1]. Nonetheless, plants have developed strategies to cope with salt stress by means of signaling pathways, which include salt sensing, salt signal generation, signal transmission, and minimizing salt damage to plants [2,3].

Phospholipids, which make up the bio-membranes needed for environmental separation between organelles and cytoplasm, and for separation between cells and their environment, also act as signaling compounds in salt stress response [2,4-7]. Important plant phospholipids include PC, PE, PIs, PS, PA, PG, cardiolipin, and their respective lysophospholipids, such as lysophosphatidic acid (LPA) and lysophosphatidylcholine (LPC). Common features of phospholipids are their non-polar fatty acyl chains, an important component of bio-membranes, and polar head groups, which interact with various factors in the water-soluble environment. Phospholipids have been a key focus of research in recent years, due to their important role in regulating cellular activities such as membrane rearrangement, cytoskeletal dynamics, phosphorus deficiency response, cold stress response, and salt stress response [6,8-12].

The function of phospholipids such as PA and PIs in the salt stress response mechanism has been studied extensively, mainly by analyzing the regulatory function of proteins involved in salt stress signal transduction. The salt stress signal in plants involves salt sensing, response and adaption, and requires the synergy of both plasma and organelle membranes. The determination of the function of membrane phospholipids in salt stress will help to decipher a plant's tolerance to salt stress. In this review, we will summarize the 
salt stress signals, as well as the biosynthesis and functions of the major phospholipids, PA, PIs, PS, PC, PE, and PG, in the response of plants to salt stress.

\section{Salt Stress Signals in Plants}

High salinity in plants can cause secondary stresses such as ionic stress, osmotic stress, and oxidative stress. At the same time, however, plants sense and cope with salt stress by means of ionic, osmotic, and reactive oxygen species (ROS) stress signaling pathways, phytohormone signaling, and organelle stress responses, which involve various components, such as phytohormones, osmolytes, organelles, and various proteins.

\subsection{Salt Stress Perception}

The plasma membrane, composed of proteins and lipids, is essential for the perception of salt stress. These components are also involved in triggering an immediate temporally and spatially defined increase of free cytosolic calcium $\left(\left[\mathrm{Ca}^{2+}\right]_{\mathrm{cyt}}\right)[2,13]$. By using a $\mathrm{Ca}^{2+}$-imaging-based genetic screen, one osmotic stress sensor was identified as reduced hyperosmolality-induced $\mathrm{Ca}^{2+}$ increase 1 (OSCA1), which is localized at the plasma membrane and forms a $\mathrm{Ca}^{2+}$-permeable channel sensitive to osmotic stress [14]. In addition to this, an optimized $\mathrm{Ca}^{2+}$-imaging-based genetic screen was used to identify another ionic stress sensor, glycosyl inositol phosphorylceramide (GIPC). This is a sphingolipid localized at the outer layer of the plasma membrane lipid bilayer, which binds $\mathrm{Na}^{+}$outside the cell and mediates the increase of $\left[\mathrm{Ca}^{2+}\right]_{c y t}$ inside the cell [15]. AtANNEXIN4 (AtANN4), a putative $\mathrm{Ca}^{2+}$-permeable transporter, is also involved in the increase of $\left[\mathrm{Ca}^{2+}\right]_{\text {cyt }}$ under salt stress. However, the activity of AtANN4 is further repressed by the salt overly sensitive (SOS) pathway to fine-tune the $\left[\mathrm{Ca}^{2+}\right]_{\text {cyt }}$ signal [16].

\subsection{Ionic Signaling Pathway}

The SOS pathway is a core signal transduction pathway for the salt tolerance of a plant. It is evolutionarily conserved and plays a key role in decoding the salt-induced $\left[\mathrm{Ca}^{2+}\right]_{\text {cyt }}$ signal in extruding excess $\mathrm{Na}^{+}$out of the cells. After perceiving $\left[\mathrm{Ca}^{2+}\right]_{\text {cyt }}$ by the $\mathrm{Ca}^{2+}$-binding proteins SOS3 and SOS3-like $\mathrm{Ca}^{2+}$-binding protein 8(SCaBP8), SOS2 kinase activity is activated, and the phosphorylated $\mathrm{Na}^{+}-\mathrm{H}^{+}$antiporter SOS1 at the plasma membrane can extrude excess $\mathrm{Na}^{+}$out of the cell $[17,18]$. In this process, the electrochemical gradient established by the plasma membrane $\mathrm{H}^{+}$-ATPase ( $\mathrm{PM} \mathrm{H}^{+}$-ATPase) drives SOS1 to transport sodium across the membrane $[17,18]$. In addition to SOS3/SCaBP8 decoding the salt-induced $\left[\mathrm{Ca}^{2+}\right]_{\mathrm{cyt}}$ signal, $14-3-3$ proteins also bind and decode the $\left[\mathrm{Ca}^{2+}\right]_{\mathrm{cyt}}$ signal to release SOS2 activity [19].

The components of the SOS pathway are regulated to cope with salt stress. When plants grow without salt stress, SOS2 kinase is inhibited by GIGANTEA (GI) and 14-33 [20,21], while PM H${ }^{+}$-ATPase activity is inhibited by SOS2-like protein5(PKS5), SCaBP1, SCaBP3, and PKS24 [22-24]. When salt stress acts on a plant, SOS2 activity is released through the degradation of GI and the 14-3-3 repressor, and is also activated by SOS3, SCaBP8, and Geminivirus Rep-Interacting Kinase 1/2 (GRIK1/2) [18,25,26]. SOS1 activity as a result of salt stress can be stimulated by SOS2 and mitogen-activated protein kinase 6 (MPK6) [18,27]. PM H${ }^{+}$-ATPase activity due to salt stress is regulated by free unsaturated fatty acids and J3 (DnaJ homolog3) [28,29]. As part of this process, free unsaturated fatty acids bind to the C-terminus of $\mathrm{PM} \mathrm{H}^{+}$-ATPase and stimulate its activity, while J3 inhibits PKS5 kinase activity to release PM H${ }^{+}$-ATPase [28,29]. When salt stress is eliminated, the SOS pathway will be inhibited to restore plant growth. This can be seen in the negative regulation of SOS2 by brassinosteroid (BR)-insensitive 2 (BIN2) [30].

Besides the SOS pathway, that can exclude $\mathrm{Na}^{+}$from the cytoplasm, an $\mathrm{Na}^{+} / \mathrm{H}^{+}$ exchanger and vacuolar $\mathrm{H}^{+}$-ATPase are activated during salt stress to help the $\mathrm{Na}^{+}$compartments inside the vacuoles [31,32]. Maintaining the $\mathrm{Na}^{+} / \mathrm{K}^{+}$ratio is critical for plant survival during salt stress. Some ion transporters, such as Arabidopsis $\mathrm{K}^{+}$transporter 
1(AKT1) and high-affinity $\mathrm{K}^{+}$channel (HKT) proteins, contribute to $\mathrm{Na}^{+} / \mathrm{K}^{+}$homeostasis [33-35].

\subsection{Osmotic Signaling Pathway}

Abscisic acid (ABA) signaling plays an essential role in the salt stress response of plants $[2,36]$. The SNF1-related protein kinase 2 (SnRK2) family of proteins are vital to the osmotic stress response $[37,38]$. It is reported that Snrk2.4 and Snrk2.10 play a positive regulatory role in salt and hyperosmotic stress responses. Their activity is induced by salt, and is localized to cellular membranes through their interaction with PA [39]. Further study revealed that SnRK2.4 and SnRK2.10 regulate root growth during salt stress, while SnRK2.1, SnRK2.5, and SnRK2.9 regulate root growth under non-salt stress conditions through the coordination of auxin signals [40]. The activity of SnRK2.4 can be inhibited by protein phosphatases $2 \mathrm{C}$ (PP2C) and ABA insensitive 2 (ABI2), while SnRK2.4 also interacts with v-myb myeloblastosis viral oncogene homolog 21 (MYB21) in the salt stress response of Arabidopsis [41,42]. In addition, the SnRK1 family of proteins, which act as an energy sensor in the regulation of cellular metabolism in response to stress, are also related to the salt stress response, since intracellular energy is closely correlated with cellular response to various stresses $[25,43,44]$. GRIKs are involved in the regulation of phosphorylation and stimulation of SnRK1 in Arabidopsis [25].

MPKs, mitogen-activated protein kinase kinases (MKKs), and mitogen-activated protein kinase kinase kinases (MKKKs) are key players in osmotic stress signal transduction [45]. There is growing evidence to show the role they play in salt stress response, such as MPK3, MPK4, MPK6, MKK4, MKK7, MKK9, MKKK20 in Arabidopsis, GhMPK17 in cotton, GMK1 in soybean, and MPKs in horticultural plants [27,46-51]. MKK1-MPK4 mediates signal transduction in rice, while its level of transcription and activity are induced by salt stress [52]. Abiotic stress-responsive Raf-like kinases (AtARKs), the subgroup B3 of the MAPKKK family, are an essential part of SnRK2-mediated osmotic stress signaling pathways [53]. MAPK cascades participate in ABA-regulated cellular activities, such as stomatal movement and seed germination [54]. The MAPK cascades also play a role in auxin signaling, ethylene signaling, BR signaling, and salicylic acid (SA) signaling, all of which are involved in the salt stress response [36,54].

Furthermore, the accumulation of osmolytes, such as sucrose, proline, and betaine in cytoplasm, also play important roles in the osmotic adjustment of salt stress [2,3].

\subsection{ROS Signaling Pathways}

ROS in plants include hydrogen peroxide $\left(\mathrm{H}_{2} \mathrm{O}_{2}\right)$, the superoxide anion $\left(\mathrm{O}_{2}{ }^{-}\right)$and the hydroxyl radical $(\cdot \mathrm{OH})$. These are produced very quickly in response to salt stress, and the regulation of ROS homeostasis in plant cells plays a very important role in salt response $[3,55,56]$. ROS is produced by the plasma membrane respiratory burst oxidase homolog (Rboh)/NADPH Oxidase (NOX) and carries out a dual function in the salt response of plants. First, ROS burst in the early stage of salt stress and act as signal molecules to transmit signals (for example, $\mathrm{RbohD}$ and $\mathrm{RbohF}$ regulate $\mathrm{Na}^{+} / \mathrm{K}^{+}$homeostasis under salt stress). Secondly, excess ROS can cause damage to lipids, proteins and DNA, and must be scavenged $[57,58]$.

\subsection{Phytohormones in Salt Stress Response}

The role of phytohormones during salt stress has been thoroughly analyzed in recent studies $[2,36]$. Both early salt stress signals and later plant growth adaption require stress response hormones, such as ABA, SA, jasmonic acid (JA), ethylene, and growth promotion hormones, such as auxin, cytokinins (CKs), BRs, gibberellin (GA), and strigolactones (SLs) [36]. Besides phytohormones, other small organic molecules such as melatonin, polyamine, GABA, and 5-aminolevulinic acid are all involved in plant salt stress response [59-62]. 


\subsection{Organelles in Salt Stress Response}

The organelles of the cell wall, endoplasmic reticulum (ER), chloroplast, mitochondrion, and peroxisome are all involved in stress response [18]. The cell wall becomes perturbed during salt stress, affecting the stress resistance of a plant [18]. Salt stress induces the rapid depolymerization of microtubules and the removal of cellulose synthase (CESA) complexes (CSCs) from plasma membranes, which impair the synthesis of cellulose and the cell wall. However, the companion of CESA (CC) proteins in CSCs promotes the reorganization of microtubules and the localization of CESA on the plasma membrane to maintain sustained cellulose synthesis and adapt to salt stress in plants [63]. Salt stress can also lead to ER stress, which is a result of an accumulation of unfolded proteins, and the ER membrane plays a role in stress sensing and signaling [18]. It is recognized that salt stress signals from organelles of the cell wall, ER, chloroplasts, mitochondria, and peroxisome are all integrated in the regulation of cellular activities during salt stress [18].

\section{PA in Salt Stress}

\subsection{PA Generation in Plants}

PA can be produced by the phospholipase D (PLD) pathway, and by the phospholipase C (PLC)-diacylglycerol kinase (DGK) pathway [64]. In the PLD pathway, PA can be produced by the hydrolysis of membrane phospholipids, such as PC and PE $[64,65]$. In the PLC-DGK pathway, PLC hydrolyzes phospholipids in the membrane to produce diacylglycerol (DAG), which is then converted into PA through a phosphorylation reaction by the catalysis of DGK [66].

\subsection{PA Functions in Salt Stress}

Although PA is a simple, common phospholipid, it has attracted the most attention in terms of plant salt stress signaling. PA in salt stress adaption will be elaborated from the following aspects (Figure 1).

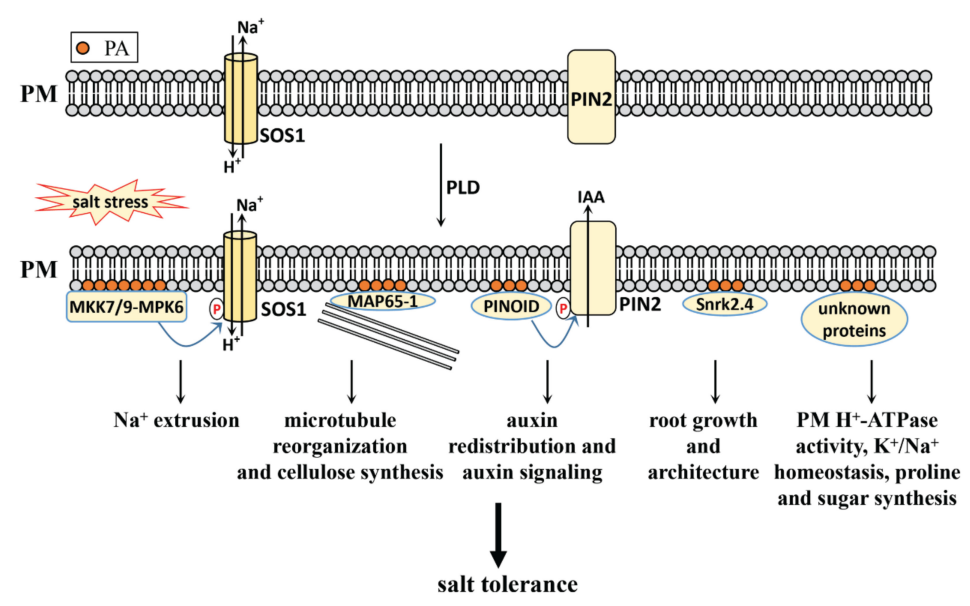

Figure 1. The regulatory role of PLD-derived PA in the salt stress response of plants. PA level is induced by salt stress. PLD $\alpha 1$-derived PA binds and activates MPK6, MKK7, and MKK9 to phosphorylate SOS1 and activate its activity in extruding excess $\mathrm{Na}^{+}$out of the cells under salt stress; PLD $\alpha 1$-derived PA can bind MAP65-1 and regulate it activity in microbutule polymerization and bundling process under salt stress, and this process may regulate cellulose synthesis in salt stress; PLD $\alpha-1$ - and PLD $\delta$-derived PA also binds PINOID and stimulates its activity in phosphorylating PIN2 to participate in salt stress response through the regulation of auxin signaling; PA regulates root growth and architecture through the interaction of Snrk2.4; PA also regulates PM H${ }^{+}$-ATPase activity, $\mathrm{K}^{+}-\mathrm{Na}^{+}$homeostasis, proline and sugar synthesis through the unidentified proteins. PM, plasma membrane; PA, phosphatidic acid; SOS1, salt overly sensitive 1; PIN2, PIN-FORMED 2; MPK, mitogen-activated protein kinase; MKK, mitogen-activated protein kinase kinase; MAP65-1, microtubule-associated protein 65-1; SnRK2.4, SNF1-related protein kinase 2.4. 


\subsubsection{PA Level Increases under Salt Stress}

Salt-induced PA accumulation has been confirmed by a large number of studies. Using the ${ }^{32} \mathrm{P}$ labeling technique, it was shown that $\mathrm{PA}$ and phosphatidylinositol bisphosphate $\left(\mathrm{PIP}_{2}\right)$ levels increased within $30 \mathrm{~min}$ of salt treatment [67-69]. The ${ }^{32} \mathrm{P}$ labeling technique can distinguish PLD-derived PA from PLC-DGK-derived PA. Specifically, PLD-derived PA can be identified by the evaluation of PLD activity. This is performed by the addition of an n-butanol inhibitor for PA generation, but also leads to the generation of a detectable amount of an unnatural product: phosphatidylbutanol (PBut) [64,70]. PLC-DGK-derived PA can be identified by the evaluation of DGK activity, by means of a reaction with ${ }^{32} \mathrm{Pi}$ labled ATP, leading to the generation of detectable radioactive PA [64,70]. Quantitation of the PA level by electrospray ionization-tandem mass spectrometry (ESI-MS/MS) supplies the information of fatty acyl chains in the accumulated PA [27]. A recently developed PA-specific biosensor, PAleon, can monitor the precise spatio-temporal dynamics of PA in living plant cells and tissues during salt stress. This suggests that PA accumulates rapidly within 10 min of salt treatment, mainly in the Arabidopsis root. The highest level is found at the tip of the root, the next highest in the maturation zone, with the lowest level found in the differentiation zone [71].

Taken together, it can be seen that PA accumulates with salt stress, indicating the regulatory role of $\mathrm{PA}$ in the related signaling.

\subsubsection{PLD-Derived PA in Salt Stress Response}

The PLD pathway contributes to the rapid accumulation of PA under salt stress. PLD in Arabidopsis has identified twelve isoforms: $\operatorname{PLD} \alpha(1,2,3), \operatorname{PLD} \beta(1,2), \operatorname{PLD} \gamma(1,2,3), \operatorname{PLD} \delta$, $\operatorname{PLD} \varepsilon$, and PLD $\zeta(1,2)[72]$. It is reported that PLD $\alpha 1, \operatorname{PLD} \alpha 3$ and PLD $\delta$ are involved in the salt stress response, and that their genetic mutations show reduced PA levels, increased $\mathrm{Na}^{+}$levels, and a salt-sensitive phenotype $[27,65,67,73]$.

It has also been reported that PLD $\alpha 1$-derived PA binds and activates MPK6, and phosphorylates the C-terminus of SOS1, thereby squeezing excess $\mathrm{Na}^{+}$from plant cells in Arabidopsis [27]. Further studies have shown that PLD $\alpha 1$-derived PA also binds and activates the upstream component of MPK6, MKK7 and MKK9, forming a MKK7/MKK9MPK6 cascade to phosphorylate SOS1 and extruding excess $\mathrm{Na}^{+}$from plant cells [50]. GMK1, a soybean MAPK, can also be stimulated by PA during the salt stress response [47]. This shows that the MAPK cascade signaling system and SOS pathway can be regulated by PLD-derived PA to improve salt tolerance in plants.

PLD $\alpha 1$-derived PA also binds to the microtubule-associated protein MAP65-1, increasing its activity in enhancing microtubule polymerization and bundling during salt stress. The mutated $p l d \alpha 1$, which features a decreased PA level, also shows a more disorganized microtubule structure compared with the wildtype [73]. As microtubule depolymerization and reorganization play key roles in cellulose synthesis under salt stress [63], the process may be regulated by PLD $\alpha 1$-derived PA through MAP65-1.

Auxin signaling adjusts root growth to adapt to salt stress, which requires auxin redistribution [36]. PIN-FORMED 2 (PIN2) trafficking and localization regulate auxin redistribution, which can be regulated by PLD $\zeta 2$ during salt stress in Arabidopsis [74]. Further study showed that PLD $\alpha 1$ - and PLD $\delta$-derived PA directly bind to PINOID kinase, promoting its accumulation on the plasma membrane and stimulating its kinase activity in phosphorylating PIN2, thereby regulating auxin efflux and auxin redistribution under salt stress in Arabidopsis [6]. This shows that the redistribution of auxin under salt stress is closely related to the increase in PA content induced by salt stress.

ABA signaling is central to the salt stress response, and PLD-derived PA regulates ABA signaling through an extensive series of interactions between PA and ABA signalingrelated proteins. PLD $\alpha 1$-derived PA binds and inhibits ABI1 activity to promote ABA signaling [75]. It binds NADPH oxidase and regulates ABA-induced ROS generation in Arabidopsis guard cells [76]. It interacts with the regulator of the G-protein signaling (RGS1) protein, and inhibits its GTPase-activity accelerating protein (GAP) activity to affect the 
G-protein regulated ABA signaling pathway [77]. It also interacts directly with sphingosine kinase (SPHK), activating it in producing phytosphingosine-1-phosphate (phyto-S1P). In contrast, SPHK and phyto-S1P act on the upstream of PLD $\alpha 1$ and PA to amplify the ABA signal and mediate ABA responses [78]. PA also binds to the guanine nucleotide exchange factor 8 (GEF8), and is essential for ABA-stimulated GEF8 activity towards ROP7. This indicates PA's role in ABA signaling through the regulation of GEF8 [79]. Although the link between PLD-derived PA and ABA signaling has been established, whether their interaction functions in salt stress remains unclear. It is reported that Snrk2.4, a member of Snrk2s, can be recruited to the cellular membranes in response to salt stress in Arabidopsis through an ABA-independent pathway [39].

Besides Arabidopsis, the role of PLD-derived PA in salt stress in other plants has also been studied. Rice suspension-cultured cells treated with salt stress showed increased PLD $\alpha$ activity, as well as increased PLD $\alpha$ protein localization in the tonoplast and plasma membrane [80]. Further genetic studies on PLD $\alpha$ knockdown mutations also indicate that PLD $\alpha$ regulates the rice salt stress response through the mediation of $\mathrm{PM} \mathrm{H}^{+}$-ATPase activity and transcription level of OsVHA-A (which encodes tonoplast $\mathrm{H}^{+}$-ATPase), OSA2 (encoding PM H $\mathrm{H}^{+}$-ATPase), and OsNHX1 (encoding TP $\mathrm{Na}^{+} / \mathrm{H}^{+}$antiporter) [80]. The phospholipase $D \alpha$ gene (AnPLD $\alpha$ ) from the xerophyte Ammopiptanthus nanus is up-regulated by high salt, and its heterologous expression in Arabidopsis can improve plant salt tolerance [81]. The heterologous expression of a cucumber phospholipase D $\alpha$ gene (CsPLD $\alpha)$ in tobacco (Nicotiana tabacum) enhances its salt tolerance by maintaining $\mathrm{Na}^{+} / \mathrm{K}^{+}$homeostasis, preventing lipid peroxidation, and accumulating osmoprotective compounds such as proline, soluble sugars, and soluble proteins [82]. In tomatoes (Lycopersicon esculentum), $L e P L D \alpha 1$ is transcriptionally up-regulated and the protein is activated upon exposure to salt in cell suspension cultures. However, further genetic analysis showed that the reduced expression of $L e P L D \alpha 1$ does not affect salt tolerance [67]. These results indicate a broad role of PLD-derived PA in the salt stress response.

\subsubsection{PLC-DGK-Derived PA in Salt Stress Response}

PLC-DGK-derived PA is also involved in the salt stress response. PLCs in plants are divided into two groups: PI-PLCs and non-specific PLCs (NPCs). PI-PLCs catalyze the hydrolysis of PIs, such as phosphatidylinositol (PI), PI 3-phosphate (PI3P), PI 4-phosphate (PI4P), and PI 4,5-bisphosphate $\left(\mathrm{PI}(4,5) \mathrm{P}_{2}\right)$. These produce DAG and inositol head groups. NPCs catalyze the hydrolysis of common phospholipids, such as PC and PE, to produce DAG and the corresponding head groups $[83,84]$. The roles of PI-PLCs and NPCs in the salt stress response will be discussed in the later sections on PIs and PC/PE.

DGKs in Arabidopsis comprise 7 members (AtDGK1-7), and in rice comprise 8 (OsDGK18) $[66,85]$. The role of DGKs in the salt stress response will be discussed in the later sections on PI-PLC and NPC.

\section{PI, PIP, and PIP ${ }_{2}$ in Salt Stress}

\subsection{PI, PIP, and PIP $P_{2}$ Generation in Plants}

PIs in plants primarily include PI, PI3P, PI4P, PI $(4,5) \mathrm{P}_{2}$, and PI 3,5-bisphosphate $\left(\mathrm{PI}(3,5) \mathrm{P}_{2}\right)$. Their metabolism in plants has been well characterized and discussed [86], so we will only perform a brief review.

The phosphorylation of PI at position D-3 produces PI3P, and at position D-4 produces PI4P. This is achieved through the catalysis of PI 3-kinase (PI3K) and PI 4-kinase (PI4K), respectively. The further phosphorylation of PI4P at position D-5 generates PI $(4,5) \mathrm{P}_{2}$ through catalysis of PI4P-5 kinase (PI4P5K), while the further phosphorylation of PI3P at position D-5 generates $\mathrm{PI}(3,5) \mathrm{P}_{2}$ by means of catalysis of PI3P-5 kinase (PI3P5K) [86,87].

PI3K in mammalian cells are made up of three types (class-I, -II, and -III); however, only the type III PI3K/vacuolar protein sorting 34 (VPS34) has been identified in Arabidopsis [88,89]. The PI4K in Arabidopsis consists of twelve isoforms, of which the type III subfamily (PI4K $\alpha 1, \alpha 2, \beta 1$ and $\beta 2$ ) is involved in the synthesis of PI4P, while the type 
II subfamily (PI4K $\gamma 1-8$ ) does not harbor PI4K activity [86,90,91]. PI4P5K in Arabidopsis are divided into two subfamilies: subfamily B consists of isoforms of PI4P5K1-9, while subfamily A consists of isoforms of PI4P5K10-11 [86,90]. The PI3P5K in Arabidopsis contains four isoforms, but only one showed catalytic activity in in vitro experiments $[86,90]$.

\subsection{PI, PIP and PIP 2 Function in Salt Stress}

Due to the metabolic connection between these PIs, we characterize this part into three sections: PI, PI4P and PI $(4,5) \mathrm{P}_{2}$ as the first section, $\mathrm{PI} 3 \mathrm{P}, \mathrm{PI}(3,5) \mathrm{P}_{2}$ as the second section, and PI-PLC as the third section. PIs in salt stress adaption will be elaborated in terms of the following aspects.

\subsubsection{PI, PI4P, and PI $(4,5) \mathrm{P}_{2}$ in Salt Stress}

$\mathrm{PI}$ and PI4P are involved in the salt stress response (Figure 2). Our recent study revealed that PI binds the C-terminus of $\mathrm{PM} \mathrm{H}^{+}$-ATPase and inhibits its activity under normal conditions (without salt stress). However, salt stress does induce the turnover of PI to PI4P, which in turn stimulates SOS1 activity to exclude excess $\mathrm{Na}^{+}$from the cell. This turnover is genetically evidenced by the PI synthase mutations pis1-1 and pis1-2, which feature a reduced PI level and the salt-tolerant phenotype, and also by the PI4P synthase mutation pi4k $\beta 1$, which has a reduced PI4P level and the salt-sensitive phenotype [92]. Our study reveals that the metabolic turnover of PIs plays a key role in salt stress response.

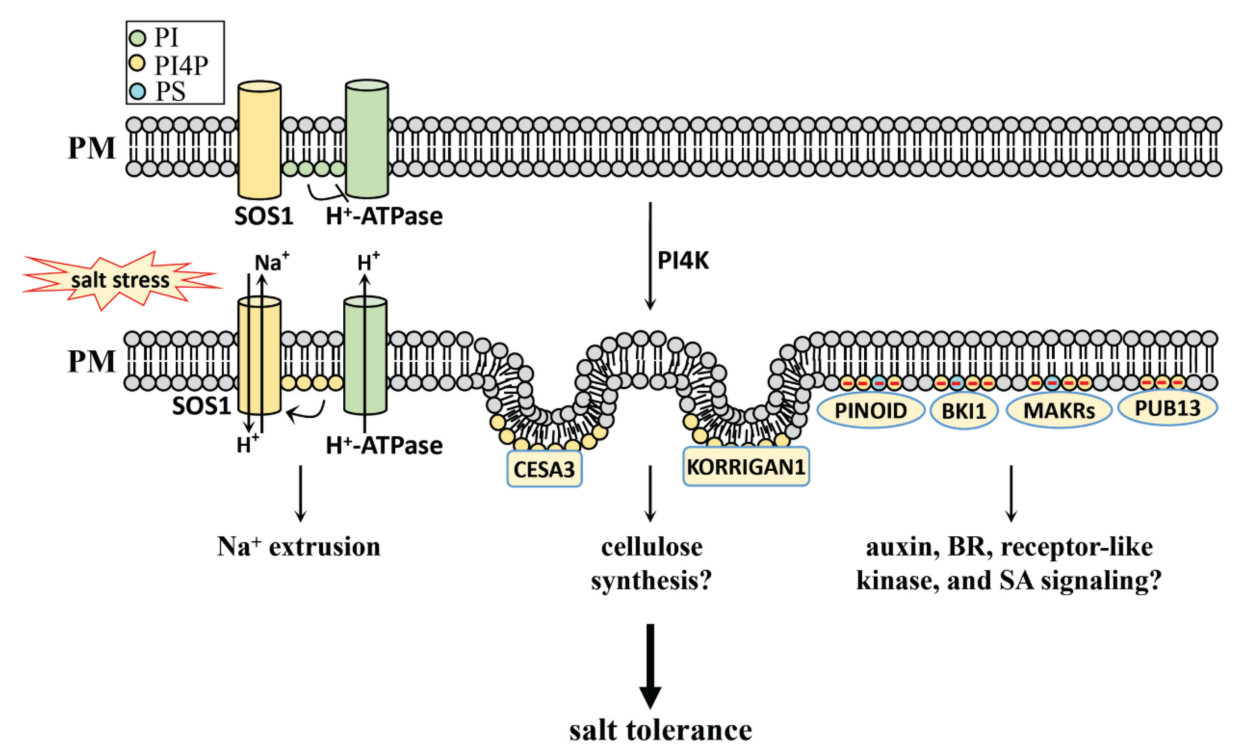

Figure 2. The regulatory role of PI4P in the salt stress response of plants. PI4P level is induced by salt stress. PI binds $\mathrm{PM} \mathrm{H}^{+}$-ATPase and inhibits its activity under normal conditions without salt stress; however, under salt stress condition, PI4P derived from PI stimulates SOS1 activity and excludes excess $\mathrm{Na}^{+}$from plant cells; PI4P also mediates the internalization of CESA3 and KORRIGAN1 from the plasma membrane, which may participate in salt stress response through the regulation of cellulose synthesis; PI4P at the plasma membrane generates an electrostatic field, which may interact with PINOID, BKI1, MAKRs, and PUB13, and participate in salt stress response. PI, phosphatidylinositol; PI4P, PI 4-phosphate; PS, phosphatidylserine; PM: plasma membrane; SOS1, salt overly sensitive 1; BKI1, BRI1 kinase inhibitor 1; MAKRs, membrane associated kinase regulators; PUB13: PLANT U-BOX13; BR, brassinosteroid; SA, salicylic acid.

PI4P and PI(4,5) $\mathrm{P}_{2}$ are mostly localized at the plasma membrane in Arabidopsis, while PI4P is also found accumulated in the apoplast of tomatoes [93,94]. The large accumulation of PI4P at the plasma membrane is a critical hallmark, since it generates an electrostatic field and controls signal transduction for various cellular activities such as cell development, reproduction, and nutrition [95]. This PI4P-driven electrostatic field may control protein 
localization on the plasma membrane during salt stress. This includes the auxin signal component PINOID, the BR signal component BRI1 KINASE INHIBITOR1 (BKI1), and the receptor-like kinase signal component membrane associated kinase regulators (MAKRs), which may also be involved in salt stress tolerance $[6,95,96]$. It is reported that PI4K is also involved in the internalization of clathrin-mediated CESA3 from the plasma membrane, as well as in the internalization and active removal of a membrane-bound cellulase KORRIGAN1 from the plasma membrane [97,98]. The evidence that PI4K participates in membrane trafficking is also supported by its role in lateral root formation through endocytic trafficking [99]. Although the link between the PI4P-driven electrostatic field and membrane trafficking activities during the salt stress response remains unclear, it is possible that PI4P may participate in the salt stress response through the determination of the electrostatic field of the membrane, further influencing its trafficking functions.

It has been reported that SA is also involved in the salt stress response [100-102]. PI4K has been found in SA signaling, as a part of which PI4K activity is stimulated by SA, while SA accumulates in the pi4kIII $\beta 1 \beta 2$ mutation in Arabidopsis [103-105]. PI4P can bind to PLANT U-BOX13 (PUB13) and suppress SA-mediated plant defense signals in uninfected Arabidopsis [106]. Whether the PI4P-regulated SA signaling functions as a salt stress response needs further study.

Besides PI4P, its product $\mathrm{PI}(4,5) \mathrm{P}_{2}$ also participates in salt stress response (Figure 3 ), and $\mathrm{PI}(4,5) \mathrm{P}_{2}$ is also localized at the plasma membrane in Arabidopsis [94]. The rapid accumulation of $\mathrm{PI}(4,5) \mathrm{P}_{2}$ was found in salt-stressed Arabidopsis, accompanied by an increased level of $\mathrm{IP}_{3}$ and $\left[\mathrm{Ca}^{2+}\right]_{\text {cyt }}$, indicating that $\mathrm{PI}(4,5) \mathrm{P}_{2}$ is involved in the salt stress response through its hydrolytic products $\mathrm{IP}_{3}$ and $\left[\mathrm{Ca}^{2+}\right]_{\mathrm{cyt}}[68,107]$.

Auxin plays a critical role in the response to salt stress, and plants respond by inhibiting root growth and rewiring their root system architecture by means of auxin signaling $[2,108]$. Auxin treatment modulates PI levels at the plasma membrane with increased $\mathrm{PI}(4,5) \mathrm{P}_{2}$ and decreased PI4P through the modulation of PI4P5K1 and PI4P5K2 [109]. The clathrin-mediated membrane trafficking regulated by $\mathrm{PI}(4,5) \mathrm{P}_{2}$ is necessary for polar positioning of PIN proteins, further affecting auxin signaling in cell functions such as root gravitropism [109-111]. Since PA also plays a role in the regulation of PIN2-mediated auxin signaling through the regulation of PINOID during salt stress [6], it is unclear whether $\mathrm{PI}(4,5) \mathrm{P}_{2}$ can coordinate with PA to regulate PIN2 under salt stress conditions. An elucidation of the link between salt-induced $\mathrm{PI}(4,5) \mathrm{P}_{2}$ accumulation and the auxin signaling can help to further decipher the mechanism of the salt stress response.

The role of $\mathrm{PI}(4,5) \mathrm{P}_{2}$ in vesicular trafficking during salt stress has been previously reported $[112,113]$ Recent research on Arabidopsis shows that the accumulation of PI(4,5) $\mathrm{P}_{2}$ in plasma membranes induced by salt stress can act as a molecular signal for the salt stress-induced ER and plasma membrane connectivity [114]. This is achieved by means of $\mathrm{PI}(4,5) \mathrm{P}_{2}$-mediated synaptotagmin 1 (SYT1)-enriched ER-PM contact site expansion [114]. $\mathrm{PI}(4,5) \mathrm{P}_{2}$ mediated vesicular trafficking and non-vesicular communication at inter-organelle membrane contact sites under salt stress further support the signal transduction role of phospholipids, in addition to them being a basic component of the membrane structure.

Polyamines play an important role in salt stress tolerance in various plant species such as sugar beet, Luffa acutangula, canola and Arabidopsis [59,115-118]. Spermine treatment triggers an increase of $\mathrm{PI}(4,5) \mathrm{P}_{2}$ in Arabidopsis root cells, and is a substance involved in regulating $\mathrm{K}^{+}$homeostasis in plants [119]. The plasma membrane-localized polyamine transporter 3 (PUT3) physically interacts with SOS1 and SOS2, while the transport activity of each is regulated under stress conditions in Arabidopsis [59]. Whether polyamine signaling is regulated by $\mathrm{PI}(4,5) \mathrm{P}_{2}$, remains unclear and requires further study. 


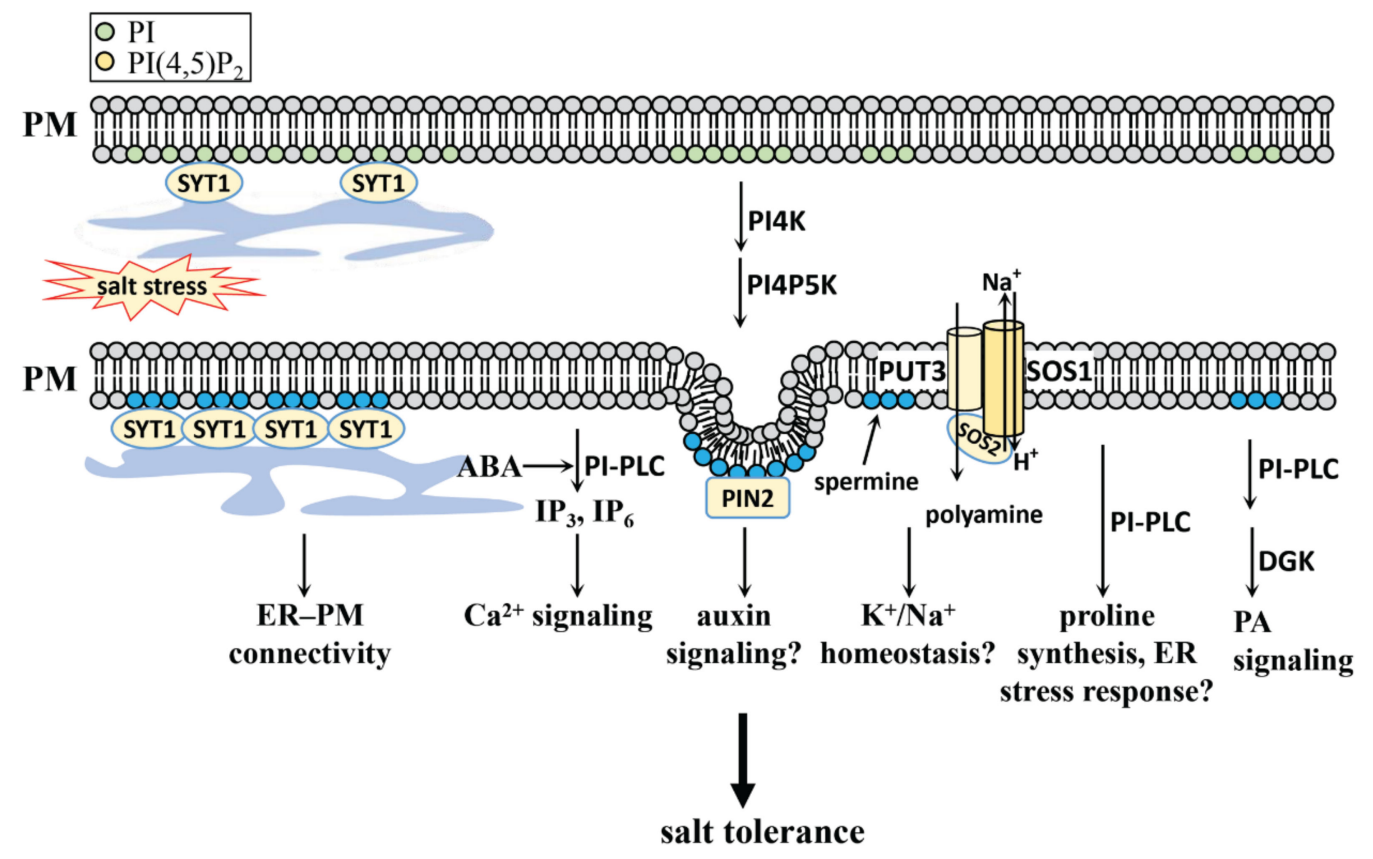

Figure 3. The regulatory role of $\mathrm{PI}(4,5) \mathrm{P}_{2}$ in the salt stress response of plants. $\mathrm{PI}(4,5) \mathrm{P}_{2}$ level is induced by salt stress. PI $(4,5) \mathrm{P}_{2}$ at the plasma membrane interacts with SYT1 and mediates the salt stress-induced ER and plasma membrane connectivity. The membrane trafficking regulation of PIN2 by $\mathrm{PI}(4,5) \mathrm{P}_{2}$ may participate in salt stress response through the regulation of auxin signaling. PUT3, a polyamine uptake transporter, interacts with SOS1 and SOS2 under salt stress condition, and the application of spermine can induce $\mathrm{PI}(4,5) \mathrm{P}_{2}$ accumulation, which indicate a possible link between polyamine, $\mathrm{PI}(4,5) \mathrm{P}_{2}$ and $\mathrm{Na}^{+}$extrusion under salt stress condition. The hydrolysis of $\mathrm{PI}(4,5) \mathrm{P}_{2}$ by PI-PLC can produce inositol phosphates, which is involved in $\mathrm{Ca}^{2+}$ stimulation under salt stress condition, and ABA may participate in this process by the regulation of PLC activity. PI-PLC may also participate in salt stress response by the regulation of proline synthesis and ER stress response, and the further catalysis by DGK can improve plant salt tolerance through PA signaling. PI, phosphatidylinositol; PI(4,5) $\mathrm{P}_{2}$, PI 4,5-bisphosphate; PM, plasma membrane; SYT1, synaptotagmin 1; PM, plasma membrane; ER, endoplasmic reticulum; ABA, abscisic acid; PI-PLC, phosphatidylinositol-phospholipase C; PIN2, PIN-FORMED 2; DGK, diacylglycerol kinase; PUT3: polyamine uptake transporter 3; SOS, salt overly sensitive.

\subsubsection{PI3P, $\mathrm{PI}(3,5) \mathrm{P}_{2}$ in Salt Stress}

$\mathrm{PI} 3 \mathrm{P}$ and $\mathrm{PI}(3,5) \mathrm{P}_{2}$ participate in the salt stress response by regulating various cellular activities (Figure 4). Unlike PI4P, which has the highest plasma membrane content, PI3P is more evenly distributed throughout the endomembrane [94].

PI3K has been reported to play a positive role in the regulation of plasma membrane endocytosis and in the production of intracellular NADPH oxidase-derived ROS during salt stress [120]. The PI3K-regulated ROS generation plays a vital role in regulating rice seed vigor [121], as well as ABA-induced ROS generation and stomata closure [122-124]. Although PI3K plays a role in ROS signaling during salt stress, exactly how PI3P regulates ROS production and how PI3K enzyme activity is regulated by salt stress still requires further study.

Autophagy is rapidly induced by salt stress and is required for the salt stress response [125-128]. PI3P can bind to the BAR-domain Protein SH3P2 and regulates autophagosome formation in Arabidopsis [129]. PI3K complex promotes autophagy and the autophagy-related 14 (ATG14)/VPS38 mutation collection permits the study of PI3P function in plant autophagy [89]. PI3P may participate in the salt stress response by regulating the autophagy process, though further research and evidence are needed. 
In addition, PI3K is involved in regulating phytohormone-mediated cellular activities. Examples include the promotion of ethylene biosynthesis to accelerate flower senescence in transgenic Nicotiana tabacum [130], the regulation of GA-stimulated $\alpha$-amylase secretion in barley (Hordeum vulgare) [131], and the delay of methyl JA (MeJA)-induced leaf senescence in Arabidopsis [132,133]. Ethylene, GA, and MeJA are all reported to play regulatory roles during salt stress [134-137]. Although the link between PI3P and these phytohormonemediated salt stress responses remains unclear, phytohormones may participate in salt stress partly through PI3P. What is more, PI3K also plays a regulatory role in the proline catabolism of Arabidopsis, which may play a role in salt stress response [138].

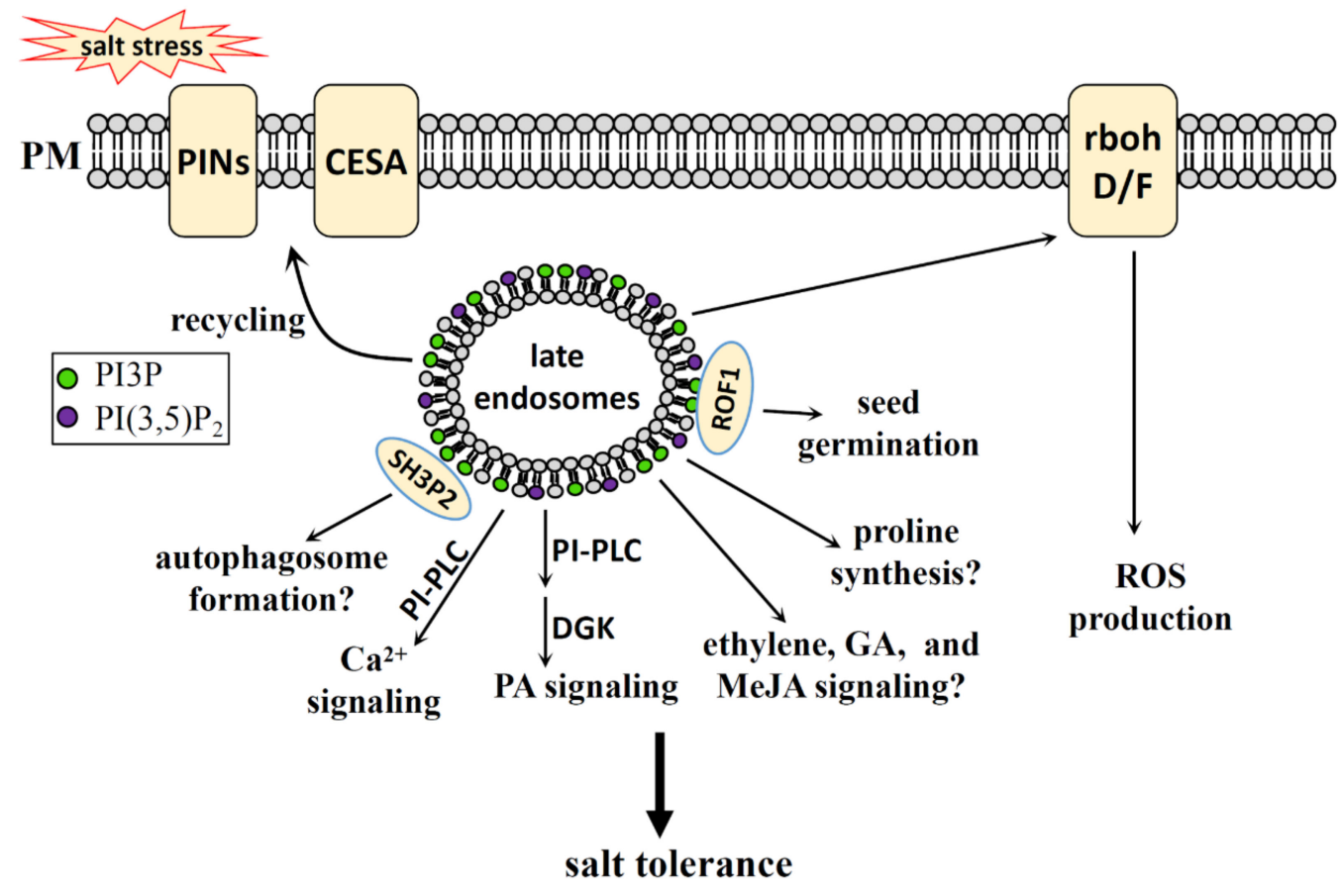

Figure 4. The regulatory role of $\mathrm{PI} 3 \mathrm{P}$ and $\mathrm{PI}(3,5) \mathrm{P}_{2}$ in the salt stress response of plants. PI3P and $\mathrm{PI}(3,5) \mathrm{P} 2$ mainly reside in late endosomes. PI3K and its product PI3P play a role in ROS production under salt stress, and rbohD/F may mediate this process. PI3P interacts with SH3P2, which may mediate autophagosome formation under salt stress. PI3K may also participate in salt stress response by its regulation function on ethylene, GA, and MeJA signalings, and proline biosynthesis. PI3P and $\mathrm{PI}(3,5) \mathrm{P}_{2}$ regulate plant salt tolerance by their regulatory roles on the recycling of PINs and CESA from late endosomes under salt stress. $\mathrm{PI}(3,5) \mathrm{P}_{2}$ can interact with $\mathrm{ROF} 1$ and regulate plant seed germination under salt stress. The hydrolysis of $\mathrm{PI}(3,5) \mathrm{P}_{2}$ by PI-PLC can produce inositol phosphates, which is involved in $\mathrm{Ca}^{2+}$ stimulation under salt stress condition, and $\mathrm{ABA}$ may participate in this process by the regulation of PLC activity. The hydrolysis of PI $(3,5) \mathrm{P}_{2}$ by PI-PLC and the further catalysis by DGK can improve plant salt tolerance through PA signaling. PI3P, PI 3-phosphate; $\mathrm{PI}(3,5) \mathrm{P}_{2}$, PI 3,5-bisphosphate; PM, plasma membrane; PIN, PIN-FORMED; CESA: cellulose synthase; SH3P2, SH3 domain-containing protein 2; PI-PLC, phosphatidylinositol-phospholipase C; DGK, diacylglycerol kinase; PA, phosphatidic acid; GA, gibberellin; MeJA, methyl jasmonic acid; ROS, reactive oxygen species; rbohD/F, respiratory burst oxidase homolog $\mathrm{D} / \mathrm{F}$.

PI3P5K, which catalyzes the synthesis of $\mathrm{PI}(3,5) \mathrm{P}_{2}$ from PI3P, mediates the maturation process of the late endosomes and the recycling of auxin transporters, which in turn affects the interaction of endosome-cortical microtubules in terms of their organization and auxin signaling $[139,140]$. In addition, the recycling of CESA complex from late endosomes is also regulated by PI3P in Arabidopsis under salt stress [97]. Many cellular activities in the salt stress response, such as cell wall synthesis, involve this recycling activity, and PI3P and $\mathrm{PI}(3,5) \mathrm{P}_{2}$ may be the major phospholipids regulating this process.. 
$\mathrm{PI}(3,5) \mathrm{P}_{2}$ and PI3P can also directly bind to immunophilin ROF1, an isoform of the FK506-Binding Protein (FKBP) subfamily, to mediate the regulatory role of ROF1 on seed germination under osmotic/salt stress in Arabidopsis [141].

\subsubsection{PI-PLC in Salt Stress Response}

The catalysis of PI-PLC consumes PIs and generates a product of DAG and inositol head groups. PI-PLC in Arabidopsis consists of nine constituent parts: AtPI-PLC1 to AtPIPLC9 $[83,84]$. The $\mathrm{Ca}^{2+}$ signal may mediate the function of PI-PLCs as part of the salt stress response. AtPI-PLC4 in Arabidopsis negatively regulates the salt stress response with a salt-hypersensitive phenotype and a more strongly salt-induced $\left[\mathrm{Ca}^{2+}\right]_{\mathrm{cyt}}$ signal in its overexpression lines compared with the control [7]. PI-PLC in rice is made up of four components: OsPI-PLC1 to OsPI-PLC4. OsPI-PLC4 positively regulates the salt stress response, with its mutation having a salt allergy phenotype. Its overexpression line has a salt-tolerant phenotype, while the PA and $\mathrm{Ca}^{2+}$ signals mediate the OsPI-PLC4regulated salt stress response $[142,143]$. OsPLC1 in rice also plays a positive role in the salt stress response. Part of this involves OsPLC1 being recruited to the plasma membrane, hydrolyzing the substrates of $\mathrm{PI}(4,5) \mathrm{P}_{2}$ and PI4P to generate DAG and $\mathrm{IP}_{3}$, and further inducing an increase in the $\left[\mathrm{Ca}^{2+}\right]_{\text {cyt }}$ signal [144].

The $\left[\mathrm{Ca}^{2+}\right]_{\text {cyt }}$ signal in animal cells is induced by $\mathrm{IP}_{3}$, while in plant cells, it is reported that $\mathrm{IP}_{6}$ also mobilizes intracellular $\mathrm{Ca}^{2+}$, thereby inducing the $\left[\mathrm{Ca}^{2+}\right]_{\text {cyt }}$ signal $[7,145,146]$. The accumulation of $\mathrm{PI}(4,5) \mathrm{P}_{2}$ and $\mathrm{PI}(3,5) \mathrm{P}_{2}$ during salt stress, and further $\left[\mathrm{Ca}^{2+}\right]_{\text {cyt }}$ signal production can be a strategy for plant salt tolerance. However, the $\left[\mathrm{Ca}^{2+}\right]_{\text {cyt }}$ signal is induced more quickly than the accumulation of $\mathrm{PI}(4,5) \mathrm{P}_{2}$ and $\mathrm{PI}(3,5) \mathrm{P}_{2}$; the explanation for this is still unknown.

ABA plays an important role in the salt stress response [36]. ABA can induce the PLC1 activity and $\mathrm{IP}_{3}$ level in Arabidopsis, while salt stress induces the expression of AtPI-PLC1 in Arabidopsis, indicating a role of AtPLC1 in the ABA-mediated salt stress response $[146,147]$. The ABA-regulated stomatal aperture is involved in coping with $\mathrm{NaCl}-$ induced osmotic stress for plants, and PI-PLCs (such as AtPI-PLC7 and AtPI-PLC3) have been reported as playing a role in ABA signaling by controlling the stomatal aperture in Arabidopsis [36,148-152]. The influence of PI-PLC on the stomatal aperture is also found in the sustained overexpression of BnPI-PLC2 in transgenic Brassica napus seedlings, which showed a reduced stomatal opening [153]. Although PLC activity can be regulated by ABA, the link between the ABA-mediated salt stress response and the PI-PLC-mediated type needs further study.

Plants utilize auxin signaling to reshape their root system architecture, making them better able to cope with salt stress. PI-PLC is also involved in auxin signal transduction [2,108]. AtPIPLC2 in Arabidopsis affects the polar distribution of PIN2 and regulates root development through auxin signaling [154]. Other PI-PLCs, such as AtPI-PLC3 and AtPI-PLC5, have also been reported to be involved in root growth and development [152,155]. Whether PI-PLC-regulated auxin signal transduction participates in salt tolerance remains unclear and needs further study.

Salt stress induces ER stress, and it has been reported that AtPLC2 participates in the ER stress response in Arabidopsis. However, whether AtPLC2 functions in the salt-induced ER stress response has not yet been researched $[18,156]$. Furthermore, proline builds up as a result of salt treatment, and the pharmacological method using U73122 (an Inhibitor of PLCs) can inhibit the accumulation of proline after salt treatment, but will not inhibit it after mannitol treatment, which only discriminates ionic stress and nonionic stress [157]. The regulatory role of PI-PLC in the ER stress response and proline accumulation in the salt stress response needs further study and evidence.

DAG, the product of PI-PLC and NPC, can be converted into PA by means of the catalysis of DGK. Therefore, the PLC pathway and the PLD pathway may act in combination to cope with salt stress $[158,159]$. It should be noted that PLC consumes substrates and produces substances that exert either a positive or a negative regulatory function during 
salt stress. How the regulatory roles of the substrates (such as $\mathrm{PI} 4 \mathrm{P}, \mathrm{PI}(4,5) \mathrm{P}_{2}$ ) and of the products (such as DAG, $\mathrm{PA}$, and $\mathrm{IP}_{3}$ ) can be coordinated in salt stress remains unclear, however, and further research is needed.

\section{PS in Salt Stress}

\subsection{PS Generation in Plants}

PS biosynthesis pathways differ between plant species. There are two common ways that PS biosynthesis takes place in plants: one uses cytidine diphosphate (CDP)-DAG and serine as substrates to synthesize PS by way of catalyzing CDP-DAG-dependent PS synthase (CD-PSS). The other uses serine and a phospholipid (such as PC and PE) to synthesize PS by means of an exchange reaction between phospholipid head groups and serine catalyzed by a $\mathrm{Ca}^{2+}$-dependent base-exchange-type PSS (BE-PSS) [87,160].

\subsection{PS Function in Salt Stress}

PS plays a role in the salt tolerance response of plants. PS in salt stress adaption will be discussed from the following aspects (Figure 5).

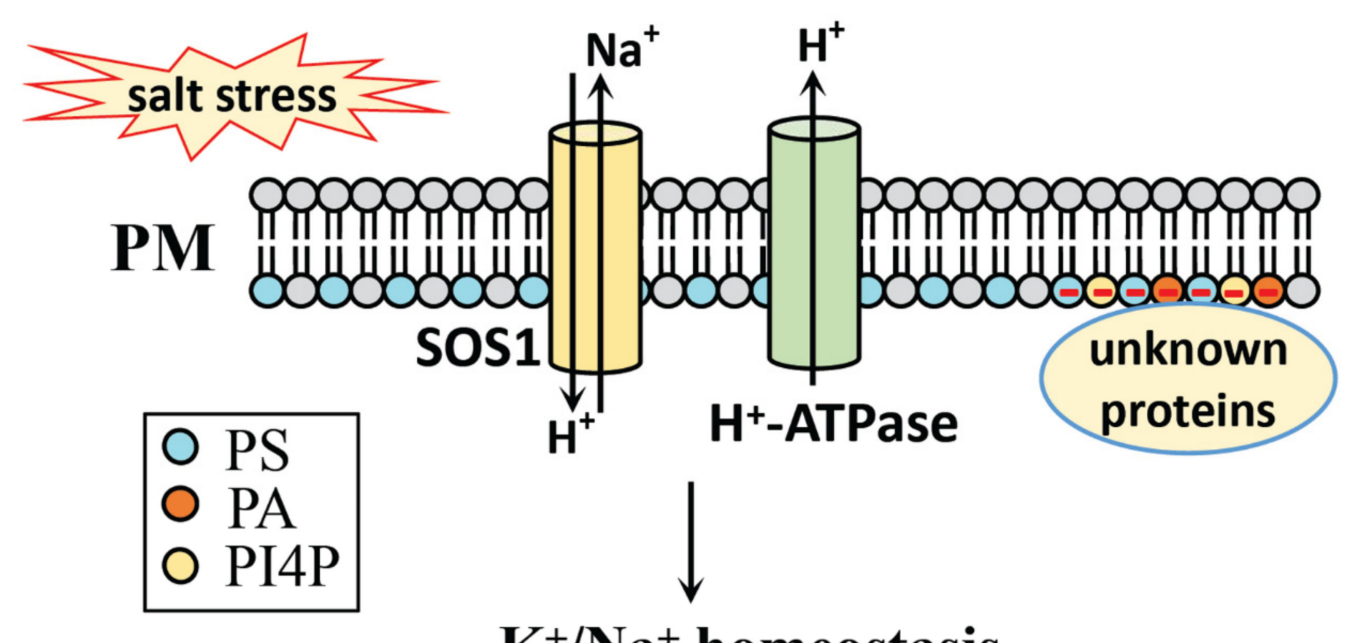

$\mathrm{K}^{+} / \mathrm{Na}^{+}$homeostasis

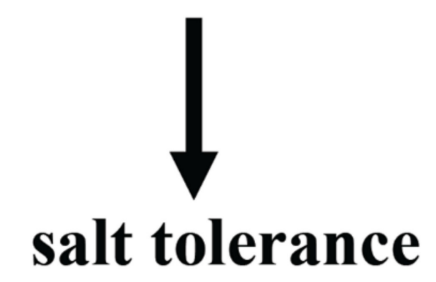

Figure 5. The regulatory role of PS in the salt stress response of plants. PS level is induced by salt stress. PS regulates $\mathrm{K}^{+} / \mathrm{Na}^{+}$homeostasis by regulating $\mathrm{PM} \mathrm{H}^{+}$-ATPase activity and SOS1 activity under salt stress. PS, together with PI4P and PA, regualtes the electronegative features of plasma membrane in plants, which may participate in salt stress response through the unknown proteins not identified yet. PS, phosphatidylserine; PA, phosphatidic acid; PI4P, PI 4-phosphate; PM, plasma membrane; SOS, salt overly sensitive.

In Salicornia europaea and Arabidopsis, salinity induces the accumulation of PS in the plasma membrane, which regulates salt tolerance by maintaining membrane stability and ion homeostasis [161]. In the salt-tolerant cultivar of sweet potato, salinity induces PS accumulation, which delays salt-induced leaf senescence, thus also reducing salt-induced $\mathrm{K}^{+}$efflux and increasing PM H${ }^{+}$-ATPase activity to positively regulate salt tolerance [162]. Overexpression of phosphatidylserine synthase IbPSS1 in sweet potato can maintain cellular $\mathrm{Na}^{+}$homeostasis and improve salt tolerance by activating the plasma membrane $\mathrm{Na}^{+} / \mathrm{H}^{+}$antiporter activity [163]. 
It is reported that PS, together with PI4P and PA, determines the electronegative features of plasma membranes in plants, which in turn regulate cellular activities by recruiting cytosolic proteins to the specific region of the membrane [164]. The small G protein Rho of Plants 6 (ROP6) can be recruited to the plasma membrane nano-domains by PS, which further participates in auxin signaling, including ROP6-mediated endocytosis and gravitropism [165]. It has been reported that ROP2 is involved in salt tolerance in Arabidopsis [166], though it is still not clear whether the PS-regulated electronegative feature of the plasma membrane and ROP6 nano-organization are involved in the salt stress response.

Together, PS participates in salt stress tolerance by regulating $\mathrm{PM} \mathrm{H}^{+}$-ATPase activity, $\mathrm{PM} \mathrm{Na}{ }^{+} / \mathrm{H}^{+}$antiporter activity, ion homeostasis, and possibly even the electrostatic field of the plasma membrane.

\section{PC, PE in Salt Stress}

\subsection{PC, PE Generation in Plants}

PC can be generated either by the reaction of CDP- choline (CDP-Cho) with DAG, or by a methylation reaction from phosphoethanolamine (P-EA) to phosphocholine (P-Cho) to further produce PC. PE can be generated either by the reaction of CDP-EA (ethanolamine) with DAG, or by a decarboxylation reaction from PS [87,167].

\subsection{PC, PE Function in Salt Stress}

Due to the metabolic depletion of PC and PE by NPC, we characterized this part into two sections: the first section looks at PC and PE in salt stress, while the second section analyzes NPC in salt stress. PC and PE in salt stress adaption will be discussed from the following aspects (Figure 6).

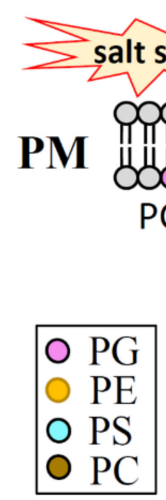
alt stress $<$
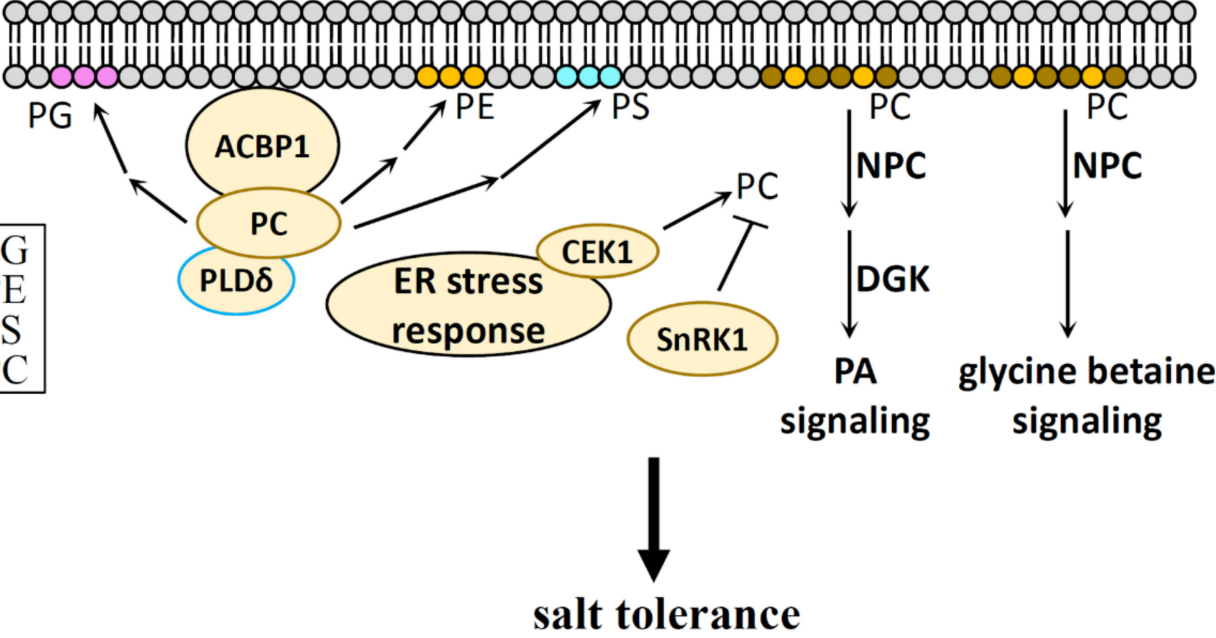

Figure 6. The regulatory role of PC and PE in the salt stress response of plants. PC improves plant salt tolerance by stabilizing the cell membrane through its conversion to PE, PS, PG, and ACBP1 and PLD $\delta$ mediate this process; The biosynthesis of PC can be regulated by SnRK1 and ER stress; The further hydrolysis of PC and PE can improce plant salt tolerance through the PA signaling and the glycine betaine signaling. PG, phosphatidylglycerol; PS, phosphatidylserine; PC, phosphatidylcholine; PE, phosphatidylethanolamine; PM, plasma membrane; ACBP1, Acyl-CoA-binding protein 1; PLD, phospholipase D; ER, endoplasmic reticulum; CEK1, choline/ethanolamine kinase 1; SnRK1; NPC, non-specific phospholipase C; DGK, diacylglycerol kinase. 


\subsubsection{PC and PE in Salt Stress}

Although PC and PE are considered structural lipids, it has been reported that salt induces PC production in Arabidopsis and maize $[168,169]$. Choline kinase is required for PC generation during salt stress [170]. PC can interact with the Acyl-CoA-binding protein 1 (ACBP1), and the heterologous expression of an $A C B P 1$ gene from saline-alkali-isolated algae (ChACBP1) in Arabidopsis improves plant salt tolerance (possibly via the mechanism of transporting $\mathrm{PC}$ to the plasma membrane), increasing PLD activity and further converting PC to PE, PS, PG to stabilize the cell membrane [171]. A recent report showed that levels of PC decreased under saline-alkaline stress in maize roots, which suggests an activated PC turnover and lipid reprogramming under saline-alkaline stress [172].

PC biosynthesis is regulated by SnRK1 through the phosphorylation and activity inhibition of CTP:phosphocholine cytidyl transferase 1 in Arabidopsis [173]. In addition to this, the transcriptional level of PC and PE biosynthesis genes are regulated under ER stress, while ER-localized choline/ethanolamine kinase 1 is required for ER stress tolerance in Arabidopsis [174,175]. These studies indicate that salt-regulated PC production may have some correlation with the cellular energy status and ER stress during salt stress.

\subsubsection{NPC in Salt Stress}

PC and PE are catalyzed by NPC and generate DAG and head groups of P-Cho and P-EA $[83,84]$. The NPC family in Arabidopsis contains six isoforms, which are named NPC1-NPC6. NPC4, with its localization in root tips and high level of expression in plasma membranes, can be transcriptionally induced and stimulated by salt $[176,177]$. The stimulation of NPC4 leads to DAG production during salt stress, and its mutation npc4, which features a decreased DAG content, shows a salt-sensitive phenotype and compromises the plant response to ABA, indicating the role of PLC-DGK-derived PA signaling and ABA signaling in NPC4-mediated salt response [176,177]. NPC5 in Arabidopsis also participates in the salt stress response, as a part of which NPC 5 is transcriptionally induced by salinity, with its knockout mutation npc5-1 showing few to no lateral roots under mild $\mathrm{NaCl}$ stress. Exogenous DAG, but not PA, can restore lateral root formation in $n p c 5-1$ under salt stress [5].

DAG, being a product of NPCs, can convert to PA, and further regulates the plant stress response through PA signaling. P-EA and P-Cho, as the other products of NPCs, can produce choline. Choline positively regulates the salt stress response of plants by regulating lipid metabolism and glycine betaine biosynthesis, and this application of choline not only leads to an increase in PC level, but also leads to an increase in other lipids, such as PE, digalactosyldiacylglycerol (DGDG), and monogalactosyldiacylglycerol (MGDG) [178-180]. This indicates that PC turnover is activated under salt stress.

Whether PE has any function during salt stress is still unknown, as is any potential mechanism for how this may happen. PC and PE residing in the membrane are considered to be structure lipids, and compared with PA and PIs, their function in salt stress response has not been analyzed in detail. Whether PC and PE play a role in the salt stress response through changes in membrane properties or as signal molecules that regulate proteins, or as substrates that produce signal molecules under salt stress, remains to be seen.

\section{PG in Salt Stress}

\subsection{PG Generation in Plants}

In the process of PG biosynthesis, PA also acts as a substrate to first synthesize CDPDAG by the catalysis of phosphatidate cytidyl transferase. CDP-DAG in chloroplasts is then converted to phosphatidylglycerol-phosphate (PGP) by the catalysis of PGP synthase, whereupon PGP is further converted to PG by the catalysis of PGP phosphatase $[87,181]$.

\subsection{PG Function in Salt Stress}

Whether PG plays a role in salt stress is still unknown. PG is considered to be a structure lipid of chloroplasts in the thylakoid membrane, a supplier of phosphate under 
phosphate-limitation conditions, and a regulator of ROP6 in plants [182-184]. Unlike other phospholipids, PG is specific to plant cells. PG has also been found in extracellular vesicles, though only in small amounts [185]. Because of the complexity of lipid transport and turnover, whether this anionic chloroplast-lipid (PG) actually regulates abiotic stress, such as salt stress, still needs to be investigated further.

\section{The Mechanism of Phospholipids in Salt Stress Response}

The amphiphilic property of phospholipids determines their localization at various cell membranes. The plasma membrane, primarily consisting of lipids and proteins, can sense extracellular salt signals and respond quickly while initiating a salt stress signal within the cells. Organelle membranes feature a unique composition of lipids and proteins, which can coordinate salt stress signals to adapt to salt stress. The complexity of phospholipids in their head groups and fatty acyl chains determines their multiple functions during cellular regulation.

\subsection{Phospholipid Head Groups in Salt Stress}

The head groups of phospholipids contain different functional groups, such as the single carboxyl group in PS, and the three methyl groups in PC. These all have different configurations (such as $\mathrm{PI}(4,5) \mathrm{P}_{2}$ and $\left.\mathrm{PI}(3,5) \mathrm{P}_{2}\right)$ and have different charges (such as $\mathrm{PA}$, PS, PIs, PG carrying negative charges), while PC and PE are neutral phospholipids under physiological $\mathrm{pH}$ conditions.

To cope with salt stress, polar head groups with hydrophilic properties are thought to be exposed to the outside of the membrane. In this way, they can communicate with other molecules; an example of this is the interaction between PA and the salt signaling proteins PINOID mentioned above [6]. Besides PA interacting with proteins, other phospholipidinteracting proteins were also identified, such as the interaction mentioned above between PI and the C-terminus of PM H ${ }^{+}$-ATPase [92], PI4P and SOS1 [92], PI4P and PUB13 [106], PI3P and ROF1 [141]. Based on this point, the regulatory role of phospholipids in salt stress is to a certain extent dependent on their binding proteins, such as the regulatory role of PA in salt stress depending in part on its interacting protein PINOID [6]. Our recent work into an improved protein-lipid overlay assay was developed based on the interaction between proteins and phospholipid head groups [186]. To monitor lipid dynamics in living plant cells and explore their roles in the regulation of cellular activities, the biosensors developed for PA, PI3P, PI4P, PI $(4,5) \mathrm{P}_{2}, \mathrm{PI}(3,5) \mathrm{P}_{2}$, and DAG were established by the fusion of the lipid-binding domain with fluorescent proteins [71,94,187-191]. The interaction between phospholipids and specific proteins may help the insertion of protein into the membrane, driving membrane bending and scission, along with further vesical formation [192].

In addition to the specific and direct interaction between phospholipids and proteins, phospholipid head groups also affect the electrostatic field of the membrane. Examples of this include PI4P in plants, which affects membrane trafficking activities, the regulation of CESA3 involved in cell wall biosynthesis, and the regulation of PINOID during auxin efflux $[95,97]$. It is also reported that the divalent metal cations, $\mathrm{Zn}^{2+}$ and $\mathrm{Ca}^{2+}$, bind to PS and induce membrane blebbing by inducing a contraction of the lipid area [193].

Taken together, phospholipids certainly play a role in salt stress, possibly through the direct interaction between their head groups and salt stress signal proteins, or through their impact on membrane surface characteristics (such as membrane electrostatic fields), to regulate salt stress signaling.

\subsection{Phospholipid Fatty Acid Chains in Salt Stress}

Non-polar fatty acid chains usually have different lengths and different degrees of unsaturation. The analysis of salt-induced PA by ESI-MS/MS revealed that $0.5 \mathrm{~h}$ of salt treatment results in an increase in PA level with the fatty acyl chains of 34:2, 34:3, 34:6, 36:3 and 36:6 [27]. C34:2-PA in Arabidopsis refers to the fatty acyl chains of 16:0 and 18:2; C34:3-PA means fatty acyl chains of 16:0 and 18:3; C34:6-PA means fatty acyl chains of 
16:3 and 18:3; C36:2-PA means fatty acyl chains of $18: 0$ and 18:2, or $18: 1$ and 18:1, or both contained; C36:6-PA means fatty acyl chains of $18: 3$ and 18:3. The difference between the fatty acyl chains at the sn-1 or sn-2 position depends on their biosynthesis pathway: prokaryotic or eukaryotic.

The identification of fatty acyl chains in phospholipids can be performed by ESIMS/MS, whose fragment ions can be obtained and fatty acyl chains determined, or by gas chromatography-mass spectrometry (GC-MS), whereby fatty acyl chains are determined from their methyl derivatives. The positional identification of fatty acyl chains at the sn-1 and sn-2 positions can be performed by tandem mass spectrometry and then deduced by means of fragment ions. This can be done, for example, via ultra-performance liquid chromatography-electrospray ionization-quadrupole-time of flight mass spectrometry (UPLC-ESI-Q-TOF MS) in the analysis of DGDG [194], or by ${ }^{13}$ C-NMR, which can also identify the position of fatty acyl chains at sn-1 or sn-2 [195]

The single C-C bond of a fatty acyl chain can rotate freely, while an unsaturated double bond cannot. This will change the local membrane properties and further affect cellular activity. Examples of this in plants include the more trienoic fatty acyl chains at low temperatures and the low trienoic fatty acyl chains at high temperatures [196]. The interaction between PA and dynamin-related protein 1 (Drp1), a mitochondrial division regulator in mice (which coincidentally interacts with the head group of PA and then penetrates into the membrane, interacting with the two saturated acyl chains of PA or adjacent phospholipids) is another example of this [197]. The short length and unsaturated nature of the fatty acyl chains will impair this interaction [197]. Similar interactions can be found in plants, such as ENTH domain-containing proteins, which form an amphipathic $\alpha$-helix $0\left(\mathrm{H}_{0}\right)$ upon recognition and binding of $\mathrm{PI}(4,5) \mathrm{P}_{2}$. The $\mathrm{H}_{0}$ helix then inserts itself into the membrane, further causing it to bend, creating membrane curvature and leading to vesical formation [192]. It is also reported that salt-induced osmotic stress can induce the rapid generation of PI4P and $\mathrm{PI}(4,5) \mathrm{P}_{2}$ with unsaturated fatty acyl chains, which are then quickly depleted to generate $\mathrm{IP}_{3}$ to cope with salt stress [198].

Taken together, the fatty acyl chains in phospholipids participate in salt stress signal transduction, possibly through their interaction proteins, or by the effect of their membrane properties.

\section{Conclusions and Outlook}

Plants respond to salt stress through a complex signal transduction involving various proteins and small molecules. Phospholipids, including PA, PIs, PS, PC, PE, and PG, have attracted more and more attention in recent years, due to the important regulatory roles they play in various cellular activities. In this review, we summarize the latest advances in salt stress signal transduction, including ion, osmosis, and ROS signaling pathways, as well as plant hormones and organelles that respond to salt stress. We also summarize the phospholipid functions in salt stress response based on their expression level, the regulation of their enzyme activity, and their biosynthesized content in response to salt stress, as well as by the salt-response phenotype of their genetic mutations. However, information on the role of phospholipids in response to salt stress is quite limited and elusive. How the turnover of phospholipids participates in salt stress response has not been studied in detail. PS, an important regulator in determining the electronegative feature of the plasma membrane in plant cells, needs to be further studied for its regulatory role in salt stress response and other cell activities. The maintenance of the $\mathrm{K}^{+} / \mathrm{Na}^{+}$ratio as regulated by phospholipids under salt stress is still not very clear, and further research is needed. Although PA and PLC play important regulatory roles in the response to salt stress, studies on the metabolite DAG in plant cells are few and far between. This metabolite plays an important regulatory role in mammalian cells. Phytohormones are also important components for a better understanding of plant salt stress, but their regulatory roles through phospholipids have not been studied in detail. Therefore, in this review, based on the regulatory role of phospholipids in other cell activities, we inferred the possible 
regulatory role of phospholipids in salt stress response through the regulated components found in salt stress signal transduction. Taken together, this paper summarizes the reported studies on phospholipids in salt stress signal transduction, and also provides information for further research on the regulatory role of phospholipids in response to salt stress.

Author Contributions: X.H. prepared the draft manuscript; Y.Y. proposed the idea, give the guidance, carry out the supervision, and the revision of the manuscript. All authors have read and agreed to the published version of the manuscript.

Funding: This research was funded by the National Natural Science Foundation of China (32000219, 31872659, 32070301); the National Natural Science Foundation of Shandong province (ZR2020MC021).

Conflicts of Interest: The authors declare no conflict of interest.

\section{References}

1. Bailey-Serres, J.; Parker, J.E.; Ainsworth, E.A.; Oldroyd, G.E.D.; Schroeder, J.I. Genetic strategies for improving crop yields. Nature 2019, 575, 109-118. [CrossRef] [PubMed]

2. Van Zelm, E.; Zhang, Y.; Testerink, C. Salt Tolerance Mechanisms of Plants. Annu. Rev. Plant. Biol. 2020, 71, 403-433. [CrossRef] [PubMed]

3. Yang, Y.; Guo, Y. Unraveling salt stress signaling in plants. J. Integr. Plant. Biol. 2018, 60, 796-804. [CrossRef] [PubMed]

4. Li, J.; Li, M.; Yao, S.; Cai, G.; Wang, X. Patatin-Related Phospholipase pPLAIII $\gamma$ Involved in Osmotic and Salt Tolerance in Arabidopsis. Plants 2020, 9, 650. [CrossRef]

5. Peters, C.; Kim, S.-C.; Devaiah, S.; Li, M.; Wang, X. Non-specific phospholipase C5 and diacylglycerol promote lateral root development under mild salt stress in Arabidopsis. Plant Cell Environ. 2014, 37, 2002-2013. [CrossRef]

6. Wang, P.; Shen, L.; Guo, J.; Jing, W.; Qu, Y.; Li, W.; Bi, R.; Xuan, W.; Zhang, Q.; Zhang, W. Phosphatidic Acid Directly Regulates PINOID-Dependent Phosphorylation and Activation of the PIN-FORMED2 Auxin Efflux Transporter in Response to Salt Stress. Plant Cell 2018, 31, 250-271. [CrossRef] [PubMed]

7. Xia, K.; Wang, B.; Zhang, J.; Li, Y.; Yang, H.; Ren, D. Arabidopsis phosphoinositide-specific phospholipase C 4 negatively regulates seedling salt tolerance. Plant Cell Environ. 2017, 40, 1317-1331. [CrossRef]

8. Li, W.; Li, M.; Zhang, W.; Welti, R.; Wang, X. The plasma membrane-bound phospholipase Ddelta enhances freezing tolerance in Arabidopsis thaliana. Nat. Biotechnol. 2004, 22, 427-433. [CrossRef] [PubMed]

9. Lin, D.; Yao, H.; Jia, L.; Tan, J.; Xu, Z.; Zheng, W.; Xue, H. Phospholipase D-derived phosphatidic acid promotes root hair development under phosphorus deficiency by suppressing vacuolar degradation of PIN-FORMED2. New Phytol. 2019, 226, 142-155. [CrossRef]

10. Pleskot, R.; Li, J.; Žárský, V.; Potocký, M.; Staiger, C.J. Regulation of cytoskeletal dynamics by phospholipase D and phosphatidic acid. Trends Plant. Sci. 2013, 18, 496-504. [CrossRef]

11. Song, P.; Jia, Q.; Chen, L.; Jin, X.; Xiao, X.; Li, L.; Chen, H.; Qu, Y.; Su, Y.; Zhang, W.; et al. Involvement of Arabidopsis phospholipase $\mathrm{D}$ delta in regulation of ROS-mediated microtubule organization and stomatal movement upon heat shock. J. Exp. Bot. 2020, 71, 6555-6570. [CrossRef]

12. Zhukovsky, M.A.; Filograna, A.; Luini, A.; Corda, D.; Valente, C. Phosphatidic acid in membrane rearrangements. FEBS Lett. 2019, 593, 2428-2451. [CrossRef]

13. Steinhorst, L.; Kudla, J. How plants perceive salt. Nature 2019, 572, 318-320. [CrossRef]

14. Yuan, F.; Yang, H.; Xue, Y.; Kong, D.; Ye, R.; Li, C.; Zhang, J.; Theprungsirikul, J.; Shrift, T.; Krichilsky, B.; et al. OSCA1 mediates osmotic-stress-evoked $\mathrm{Ca}^{2+}$ increases vital for osmosensing in Arabidopsis. Nature 2014, 514, 367-371. [CrossRef]

15. Jiang, Z.; Zhou, X.; Tao, M.; Yuan, F.; Liu, L.; Wu, F.; Wu, X.; Xiang, Y.; Niu, Y.; Liu, F.; et al. Plant cell-surface GIPC sphingolipids sense salt to trigger $\mathrm{Ca}^{2+}$ influx. Nature 2019, 572, 341-346. [CrossRef]

16. Ma, L.; Ye, J.; Yang, Y.; Lin, H.; Yue, L.; Luo, J.; Long, Y.; Fu, H.; Liu, X.; Zhang, Y.; et al. The SOS2-SCaBP8 Complex Generates and Fine-Tunes an AtANN4-Dependent Calcium Signature under Salt Stress. Dev. Cell 2019, 48, 697-709.e5. [CrossRef] [PubMed]

17. Gong, D.; Guo, Y.; Schumaker, K.S.; Zhu, J.-K. The SOS3 Family of Calcium Sensors and SOS2 Family of Protein Kinases in Arabidopsis. Plant. Physiol. 2004, 134, 919-926. [CrossRef] [PubMed]

18. Zhu, J.-K. Abiotic Stress Signaling and Responses in Plants. Cell 2016, 167, 313-324. [CrossRef] [PubMed]

19. Yang, Z.; Wang, C.; Xue, Y.; Liu, X.; Chen, S.; Song, C.; Yang, Y.; Guo, Y. Calcium-activated 14-3-3 proteins as a molecular switch in salt stress tolerance. Nat. Commun. 2019, 10, 1-12. [CrossRef] [PubMed]

20. Kim, W.-Y.; Ali, Z.; Park, H.J.; Park, S.J.; Cha, J.-Y.; Perez-Hormaeche, J.; Quintero, F.J.; Shin, G.; Kim, M.R.; Qiang, Z.; et al. Release of SOS2 kinase from sequestration with GIGANTEA determines salt tolerance in Arabidopsis. Nat. Commun. 2013, 4, 1352. [CrossRef] [PubMed]

21. Zhou, H.; Lin, H.; Chen, S.; Becker, K.; Yang, Y.; Zhao, J.; Kudla, J.; Schumaker, K.S.; Guo, Y. Inhibition of the Arabidopsis Salt Overly Sensitive Pathway by 14-3-3 Proteins. Plant Cell 2014, 26, 1166-1182. [CrossRef] 
22. Fuglsang, A.T.; Guo, Y.; Cuin, T.A.; Qiu, Q.; Song, C.; Kristiansen, K.A.; Bych, K.; Schulz, A.; Shabala, S.; Schumaker, K.S.; et al. Arabidopsis Protein Kinase PKS5 Inhibits the Plasma Membrane $\mathrm{H}^{+}$-ATPase by Preventing Interaction with 14-3-3 Protein. Plant Cell 2007, 19, 1617-1634. [CrossRef]

23. Lin, H.; Du, W.; Yang, Y.; Schumaker, K.S.; Guo, Y. A Calcium-Independent Activation of the Arabidopsis SOS2-Like Protein Kinase24 by Its Interacting SOS3-Like Calcium Binding Protein1. Plant. Physiol. 2014, 164, 2197-2206. [CrossRef] [PubMed]

24. Yang, Y.; Wu, Y.; Ma, L.; Yang, Z.; Dong, Q.; Li, Q.; Ni, X.; Kudla, J.; Song, C.; Guo, Y. The Ca2+ Sensor SCaBP3/CBL7 Modulates Plasma Membrane H+-ATPase Activity and Promotes Alkali Tolerance in Arabidopsis. Plant Cell 2019, 31, 1367-1384. [CrossRef] [PubMed]

25. Barajas-Lopez, J.D.D.; Moreno, J.R.; Gamez-Arjona, F.M.; Pardo, J.M.; Punkkinen, M.; Zhu, J.-K.; Quintero, F.J.; Fujii, H. Upstream kinases of plant SnRKs are involved in salt stress tolerance. Plant. J. 2017, 93, 107-118. [CrossRef] [PubMed]

26. Tan, T.; Cai, J.; Zhan, E.; Yang, Y.; Zhao, J.; Guo, Y.; Zhou, H. Stability and localization of 14-3-3 proteins are involved in salt tolerance in Arabidopsis. Plant. Mol. Biol. 2016, 92, 391-400. [CrossRef] [PubMed]

27. Yu, L.; Nie, J.; Cao, C.; Jin, Y.; Yan, M.; Wang, F.; Liu, J.; Xiao, Y.; Liang, Y.; Zhang, W. Phosphatidic acid mediates salt stress response by regulation of MPK6 in Arabidopsis thaliana. New Phytol. 2010, 188, 762-773. [CrossRef] [PubMed]

28. Han, X.; Yang, Y.; Wu, Y.; Liu, X.; Lei, X.; Guo, Y. A bioassay-guided fractionation system to identify endogenous small molecules that activate plasma membrane H+-ATPase activity in Arabidopsis. J. Exp. Bot. 2017, 68, 2951-2962. [CrossRef]

29. Yang, Y.; Qin, Y.; Xie, C.; Zhao, F.; Zhao, J.; Liu, D.; Chen, S.; Fuglsang, A.T.; Palmgren, M.; Schumaker, K.S.; et al. The Arabidopsis Chaperone J3 Regulates the Plasma Membrane H+-ATPase through Interaction with the PKS5 Kinase. Plant Cell 2010, 22, 1313-1332. [CrossRef]

30. Li, J.; Zhou, H.; Zhang, Y.; Li, Z.; Yang, Y.; Guo, Y. The GSK3-like Kinase BIN2 Is a Molecular Switch between the Salt Stress Response and Growth Recovery in Arabidopsis thaliana. Dev. Cell 2020, 55, 367-380.e6. [CrossRef]

31. Brini, F.; Masmoudi, K. Ion Transporters and Abiotic Stress Tolerance in Plants. ISRN Mol. Biol. 2012, 2012, 1-13. [CrossRef]

32. Yang, Y.; Guo, Y. Elucidating the molecular mechanisms mediating plant salt-stress responses. New Phytol. 2017, 217, 523-539. [CrossRef]

33. Adams, E.; Shin, R. Transport, signaling, and homeostasis of potassium and sodium in plants. J. Integr. Plant. Biol. 2014, 56, 231-249. [CrossRef]

34. Chérel, I.; Gaillard, I. The Complex Fine-Tuning of K+ Fluxes in Plants in Relation to Osmotic and Ionic Abiotic Stresses. Int. J. Mol. Sci. 2019, 20, 715. [CrossRef] [PubMed]

35. Ma, Q.; Hu, J.; Zhou, X.-R.; Yuan, H.-J.; Kumar, T.; Luan, S.; Wang, S.-M. ZxAKT1 is essential for K+uptake and $\mathrm{K}+/ \mathrm{Na}+$ homeostasis in the succulent xerophyteZygophyllum xanthoxylum. Plant. J. 2017, 90, 48-60. [CrossRef]

36. Yu, Z.; Duan, X.; Luo, L.; Dai, S.; Ding, Z.; Xia, G. How Plant Hormones Mediate Salt Stress Responses. Trends Plant. Sci. 2020, 25, 1117-1130. [CrossRef] [PubMed]

37. Fàbregas, N.; Yoshida, T.; Fernie, A.R. Role of Raf-like kinases in SnRK2 activation and osmotic stress response in plants. Nat. Commun. 2020, 11, 1-11. [CrossRef]

38. Fujii, H.; Zhu, J.-K. Osmotic stress signaling via protein kinases. Cell. Mol. Life Sci. 2012, 69, 3165-3173. [CrossRef] [PubMed]

39. McLoughlin, F.; Galvan-Ampudia, C.S.; Julkowska, M.M.; Caarls, L.; van der Does, D.; Laurière, C.; Munnik, T.; Haring, M.A.; Testerink, C. The Snf1-related protein kinases SnRK2.4 and SnRK2.10 are involved in maintenance of root system architecture during salt stress. Plant. J. 2012, 72, 436-449. [CrossRef]

40. Kawa, D.; Meyer, A.J.; Dekker, H.L.; Abd-El-Haliem, A.M.; Gevaert, K.; Van De Slijke, E.; Maszkowska, J.; Bucholc, M.; Dobrowolska, G.; De Jaeger, G.; et al. SnRK2 Protein Kinases and mRNA Decapping Machinery Control Root Development and Response to Salt. Plant. Physiol. 2019, 182, 361-377. [CrossRef] [PubMed]

41. Krzywinska, E.; Kulik, A.; Bucholc, M.; Fernandez, M.A.; Rodriguez, P.L.; Dobrowolska, G. Protein phosphatase type 2C PP2CA together with ABI1 inhibits SnRK2.4 activity and regulates plant responses to salinity. Plant. Signal. Behav. 2016, 11, e1253647. [CrossRef]

42. Zhang, X.; Wu, S.; Liu, S.; Takano, T. The Arabidopsis sucrose non-fermenting-1-related protein kinase AtSnRK2.4 interacts with a transcription factor, AtMYB21, that is involved in salt tolerance. Plant Sci. 2021, 303, 110685. [CrossRef]

43. De Col, V.; Fuchs, P.; Nietzel, T.; Elsässer, M.; Voon, C.P.; Candeo, A.; Seeliger, I.; Fricker, M.D.; Grefen, C.; Møller, I.M.; et al. ATP sensing in living plant cells reveals tissue gradients and stress dynamics of energy physiology. eLife 2017, 6, e26770. [CrossRef]

44. Lang, T.; Deng, C.; Yao, J.; Zhang, H.; Wang, Y.; Deng, S. A salt-signaling network involving ethylene, extracellular ATP, hydrogen peroxide, and calcium mediates $\mathrm{K}^{+} / \mathrm{Na}^{+}$homeostasis in Arabidopsis. Int. J. Mol. Sci. 2020, 21, 8683. [CrossRef] [PubMed]

45. Zhou, X.; Naguro, I.; Ichijo, H.; Watanabe, K. Mitogen-activated protein kinases as key players in osmotic stress signaling. Biochim. Biophys. Acta Gen. Subj. 2016, 1860, 2037-2052. [CrossRef] [PubMed]

46. He, X.; Wang, C.; Wang, H.; Li, L.; Wang, C. The Function of MAPK Cascades in Response to Various Stresses in Horticultural Plants. Front. Plant Sci. 2020, 11, 952. [CrossRef] [PubMed]

47. Im, J.H.; Lee, H.; Kim, J.; Kim, H.B.; An, C.S. Soybean MAPK, GMK1 Is dually regulated by phosphatidic acid and hydrogen peroxide and translocated to nucleus during salt stress. Mol. Cells 2012, 34, 271-278. [CrossRef] [PubMed]

48. Kim, J.-M.; Woo, D.-H.; Kim, S.-H.; Lee, S.-Y.; Park, H.-Y.; Seok, H.-Y.; Chung, W.S.; Moon, Y.-H. Arabidopsis MKKK20 is involved in osmotic stress response via regulation of MPK6 activity. Plant Cell Rep. 2011, 31, 217-224. [CrossRef] 
49. Kim, S.-H.; Woo, D.-H.; Kim, J.-M.; Lee, S.-Y.; Chung, W.S.; Moon, Y.-H. Arabidopsis MKK4 mediates osmotic-stress response via its regulation of MPK3 activity. Biochem. Biophys. Res. Commun. 2011, 412, 150-154. [CrossRef]

50. Shen, L.; Zhuang, B.; Wu, Q.; Zhang, H.; Nie, J.; Jing, W.; Yang, L.; Zhang, W. Phosphatidic acid promotes the activation and plasma membrane localization of MKK7 and MKK9 in response to salt stress. Plant. Sci. 2019, 287, 110190. [CrossRef]

51. Zhang, J.; Zou, D.; Li, Y.; Sun, X.; Wang, N.-N.; Gong, S.-Y.; Zheng, Y.; Li, X.-B. GhMPK17, a Cotton Mitogen-Activated Protein Kinase, Is Involved in Plant Response to High Salinity and Osmotic Stresses and ABA Signaling. PLoS ONE 2014, 9, e95642. [CrossRef]

52. Wang, F.; Jing, W.; Zhang, W. The mitogen-activated protein kinase cascade MKK1-MPK4 mediates salt signaling in rice. Plant. Sci. 2014, 227, 181-189. [CrossRef]

53. Katsuta, S.; Masuda, G.; Bak, H.; Shinozawa, A.; Kamiyama, Y.; Umezawa, T.; Takezawa, D.; Yotsui, I.; Taji, T.; Sakata, Y. Arabidopsis Raf-like kinases act as positive regulators of subclass III SnRK2 in osmostress signaling. Plant. J. 2020, 103, 634-644. [CrossRef]

54. Jagodzik, P.; Tajdel-Zielinska, M.; Cieśla, A.; Marczak, M.; Ludwikow, A. Mitogen-Activated Protein Kinase Cascades in Plant Hormone Signaling. Front. Plant Sci. 2018, 9, 1387. [CrossRef]

55. Ijaz, B.; Formentin, E.; Ronci, B.; Locato, V.; Barizza, E.; Hyder, M.Z.; Schiavo, F.L.; Yasmin, T. Salt tolerance in indica rice cell cultures depends on a fine tuning of ROS signalling and homeostasis. PLoS ONE 2019, 14, e213986. [CrossRef]

56. Wang, J.; Huang, R. Modulation of Ethylene and Ascorbic Acid on Reactive Oxygen Species Scavenging in Plant Salt Response. Front. Plant Sci. 2019, 10, 319. [CrossRef]

57. Ma, L.; Zhang, H.; Sun, L.; Jiao, Y.; Zhang, G.; Miao, C.; Hao, F. NADPH oxidase AtrbohD and AtrbohF function in ROS-dependent regulation of $\mathrm{Na}^{+} / \mathrm{K}^{+}$homeostasis in Arabidopsis under salt stress. J. Exp. Bot. 2011, 63, 305-317. [CrossRef]

58. Sagi, M.; Fluhr, R. Production of Reactive Oxygen Species by Plant NADPH Oxidases. Plant. Physiol. 2006, 141, 336-340. [CrossRef] [PubMed]

59. Chai, H.; Guo, J.; Zhong, Y.; Hsu, C.; Zou, C.; Wang, P.; Zhu, J.; Shi, H. The plasma-membrane polyamine transporter PUT3 is regulated by the $\mathrm{Na}+/ \mathrm{H}+$ antiporter SOS1 and protein kinase SOS2. New Phytol. 2020, 226, 785-797. [CrossRef]

60. Che-Othman, M.H.; Jacoby, R.P.; Millar, A.H.; Taylor, N.L. Wheat mitochondrial respiration shifts from the tricarboxylic acid cycle to the GABA shunt under salt stress. New Phytol. 2019, 225, 1166-1180. [CrossRef] [PubMed]

61. Sun, C.; Liu, L.; Wang, L.; Li, B.; Jin, C.; Lin, X. Melatonin: A master regulator of plant development and stress responses. J. Integr. Plant. Biol. 2020, 63, 126-145. [CrossRef]

62. Wu, Y.; Jin, X.; Liao, W.; Hu, L.; Dawuda, M.M.; Zhao, X.; Tang, Z.; Gong, T.; Yu, J. 5-Aminolevulinic Acid (ALA) Alleviated Salinity Stress in Cucumber Seedlings by Enhancing Chlorophyll Synthesis Pathway. Front. Plant Sci. 2018, 9, 635. [CrossRef]

63. Endler, A.; Kesten, C.; Schneider, R.; Zhang, Y.; Ivakov, A.; Froehlich, A.; Funke, N.; Persson, S. A Mechanism for Sustained Cellulose Synthesis during Salt Stress. Cell 2015, 162, 1353-1364. [CrossRef]

64. Testerink, C.; Munnik, T. Phosphatidic acid: A multifunctional stress signaling lipid in plants. Trends Plant. Sci. 2005, 10, 368-375 [CrossRef]

65. Hong, Y.; Pan, X.; Welti, R.; Wang, X. Phospholipase Dalpha3 is involved in the hyperosmotic response in Arabidopsis. Plant Cell 2008, 20, 803-816. [CrossRef]

66. Arisz, S.; Testerink, C.; Munnik, T. Plant PA signaling via diacylglycerol kinase. Biochim. Biophys. Acta Mol. Cell Biol. Lipids 2009, 1791, 869-875. [CrossRef]

67. Bargmann, B.O.R.; Laxalt, A.M.; ter Riet, B.; van Schooten, B.; Merquiol, E.; Testerink, C.; Haring, M.A.; Bartels, D.; Munnik, T. Multiple PLDs Required for High Salinity and Water Deficit Tolerance in Plants. Plant Cell Physiol. 2008, 50, 78-89. [CrossRef]

68. Darwish, E.; Testerink, C.; Khalil, M.; El-Shihy, O.; Munnik, T. Phospholipid Signaling Responses in Salt-Stressed Rice Leaves. Plant Cell Physiol. 2009, 50, 986-997. [CrossRef] [PubMed]

69. Munnik, T.; Meijer, H.; Ter Riet, B.; Hirt, H.; Frank, W.; Bartels, D.; Musgrave, A. Hyperosmotic stress stimulates phospholipase D activity and elevates the levels of phosphatidic acid and diacylglycerol pyrophosphate. Plant. J. 2000, 22, 147-154. [CrossRef] [PubMed]

70. Zarza, X.; Shabala, L.; Fujita, M.; Shabala, S.; Haring, M.A.; Tiburcio, A.F.; Munnik, T. Extracellular Spermine Triggers a Rapid Intracellular Phosphatidic Acid Response in Arabidopsis, Involving PLD Activation and Stimulating Ion Flux. Front. Plant Sci. 2019, 10, 601. [CrossRef] [PubMed]

71. Li, W.; Song, T.; Wallrad, L.; Kudla, J.; Wang, X.; Zhang, W. Tissue-specific accumulation of pH-sensing phosphatidic acid determines plant stress tolerance. Nat. Plants 2019, 5, 1012-1021. [CrossRef] [PubMed]

72. Bargmann, B.; Munnik, T. The role of phospholipase D in plant stress responses. Curr. Opin. Plant. Biol. 2006, 9, 515-522. [CrossRef]

73. Zhang, Q.; Lin, F.; Mao, T.; Nie, J.; Yan, M.; Yuan, M.; Zhang, W. Phosphatidic Acid Regulates Microtubule Organization by Interacting with MAP65-1 in Response to Salt Stress in Arabidopsis. Plant Cell 2012, 24, 4555-4576. [CrossRef]

74. Galvan-Ampudia, C.S.; Julkowska, M.; Darwish, E.; Gandullo, J.; Korver, R.A.; Brunoud, G.; Haring, M.A.; Munnik, T.; Vernoux, T.; Testerink, C. Halotropism Is a Response of Plant Roots to Avoid a Saline Environment. Curr. Biol. 2013, 23, $2044-2050$. [CrossRef]

75. Zhang, W.; Qin, C.; Zhao, J.; Wang, X. Phospholipase D 1-derived phosphatidic acid interacts with ABI1 phosphatase 2C and regulates abscisic acid signaling. Proc. Natl. Acad. Sci. USA 2004, 101, 9508-9513. [CrossRef] 
76. Zhang, Y.; Zhu, H.; Zhang, Q.; Li, M.; Yan, M.; Wang, R.; Wang, L.; Welti, R.; Zhang, W.; Wang, X. Phospholipase dalpha1 and phosphatidic acid regulate NADPH oxidase activity and production of reactive oxygen species in ABA-mediated stomatal closure in Arabidopsis. Plant Cell 2009, 21, 2357-2377. [CrossRef]

77. Choudhury, S.R.; Pandey, S. Phosphatidic acid binding inhibits RGS 1 activity to affect specific signaling pathways in Arabidopsis. Plant. J. 2017, 90, 466-477. [CrossRef] [PubMed]

78. Guo, L.; Mishra, G.; Markham, J.E.; Li, M.; Tawfall, A.; Welti, R.; Wang, X. Connections between Sphingosine Kinase and Phospholipase D in the Abscisic Acid Signaling Pathway in Arabidopsis. J. Biol. Chem. 2012, 287, 8286-8296. [CrossRef] [PubMed]

79. Cao, C.; Wang, P.; Song, H.; Jing, W.; Shen, L.; Zhang, Q.; Zhang, W. Phosphatidic acid binds to and regulates guanine nucleotide exchange factor 8 (GEF8) activity in Arabidopsis. Funct. Plant. Biol. 2017, 44, 1029. [CrossRef] [PubMed]

80. Shen, P.; Wang, R.; Jing, W.; Zhang, W. Rice Phospholipase D $\alpha$ is Involved in Salt Tolerance by the Mediation of $\mathrm{H}^{+}-\mathrm{ATPase}$ Activity and Transcription. J. Integr. Plant. Biol. 2010, 53, 289-299. [CrossRef]

81. Yu, H.Q.; Yong, T.M.; Li, H.J.; Liu, Y.P.; Zhou, S.F.; Fu, F.L.; Li, W.C. Overexpression of a phospholipase Dalpha gene from Ammopiptanthus nanus enhances salt tolerance of phospholipase Dalpha1-deficient Arabidopsis mutant. Planta 2015, 242, 1495-1509. [CrossRef] [PubMed]

82. Ji, T.; Li, S.; Huang, M.; Di, Q.; Wang, X.; Wei, M.; Shi, Q.; Li, Y.; Gong, B.; Yang, F. Overexpression of cucumber phospholipase $\mathrm{D}$ alpha gene (CsPLDalpha) in tobacco enhanced salinity stress tolerance by regulating $\mathrm{Na}^{+}-\mathrm{K}^{+}$balance and lipid peroxidation. Front. Plant Sci. 2017, 8, 499. [CrossRef] [PubMed]

83. Sagar, S.; Singh, A. Emerging role of phospholipase C mediated lipid signaling in abiotic stress tolerance and development in plants. Plant Cell Rep. 2021, 1-11. [CrossRef]

84. Takáč, T.; Novák, D.; Šamaj, J. Recent Advances in the Cellular and Developmental Biology of Phospholipases in Plants. Front. Plant Sci. 2019, 10, 362. [CrossRef]

85. Ge, H.; Chen, C.; Jing, W.; Zhang, Q.; Wang, H.; Wang, R.; Zhang, W. The Rice Diacylglycerol Kinase Family: Functional Analysis Using Transient RNA Interference. Front. Plant Sci. 2012, 3, 60. [CrossRef]

86. Heilmann, I. Phosphoinositide signaling in plant development. Development 2016, 143, 2044-2055. [CrossRef]

87. Fatiha, A. Plant Lipid Metabolism, Advances in Lipid Metabolism; Baez, R.V., Ed.; IntechOpen: London, UK, 2018.

88. Lee, Y.; Kim, E.-S.; Choi, Y.; Hwang, I.; Staiger, C.J.; Chung, Y.-Y.; Lee, Y. The Arabidopsis Phosphatidylinositol 3-Kinase Is Important for Pollen Development. Plant. Physiol. 2008, 147, 1886-1897. [CrossRef]

89. Liu, F.; Hu, W.; Li, F.; Marshall, R.S.; Zarza, X.; Munnik, T.; Vierstra, R.D. AUTOPHAGY-RELATED14 and Its Associated Phosphatidylinositol 3-Kinase Complex Promote Autophagy in Arabidopsis. Plant Cell 2020, 32, 3939-3960. [CrossRef]

90. Heilmann, M.; Heilmann, I. Plant phosphoinositides-Complex networks controlling growth and adaptation. Biochim. Biophys. Acta Mol. Cell Biol. Lipids 2015, 1851, 759-769. [CrossRef] [PubMed]

91. Tang, Y.; Zhao, C.Y.; Tan, S.T.; Xue, H.W. Arabidopsis type II phosphatidylinositol 4-Kinase PI4Kgamma5 regulates auxin biosynthesis and leaf margin development through interacting with membrane-bound transcription factor ANAC078. PLoS Gene 2016, 12, e1006252.

92. Yang, Y.; Han, X.; Ma, L.; Wu, Y.; Liu, X.; Fu, H.; Liu, G.; Lei, X.; Guo, Y. Dynamic changes of phosphatidylinositol and phosphatidylinositol 4-phosphate levels modulate $\mathrm{H}^{+}$-ATPase and $\mathrm{Na}^{+} / \mathrm{H}^{+}$antiporter activities to maintain ion homeostasis in Arabidopsis under salt stress. Mol. Plant. 2021. [CrossRef]

93. Gonorazky, G.; Laxalt, A.M.; Dekker, H.L.; Rep, M.; Munnik, T.; Testerink, C.; de la Canal, L. Phosphatidylinositol 4-phosphate is associated to extracellular lipoproteic fractions and is detected in tomato apoplastic fluids. Plant. Biol. 2011, 14, 41-49. [CrossRef]

94. Simon, M.L.A.; Platre, M.P.; Assil, S.; Van Wijk, R.; Chen, W.Y.; Chory, J.; Dreux, M.; Munnik, T.; Jaillais, Y. A multi-colour/multiaffinity marker set to visualize phosphoinositide dynamics in Arabidopsis. Plant. J. 2013, 77, 322-337. [CrossRef]

95. Simon, M.L.A.; Platre, M.P.; Marquès-Bueno, M.M.; Armengot, L.; Stanislas, T.; Bayle, V.; Caillaud, M.-C.; Jaillais, Y. A PtdIns(4)Pdriven electrostatic field controls cell membrane identity and signalling in plants. Nat. Plants 2016, 2, 1-10. [CrossRef] [PubMed]

96. Hoffmann, N.; King, S.; Samuels, A.L.; McFarlane, H.E. Subcellular coordination of plant cell wall synthesis. Dev. Cell 2021, 56, 933-948. [CrossRef] [PubMed]

97. Fujimoto, M.; Suda, Y.; Vernhettes, S.; Nakano, A.; Ueda, T. Phosphatidylinositol 3-Kinase and 4-Kinase Have Distinct Roles in Intracellular Trafficking of Cellulose Synthase Complexes in Arabidopsis thaliana. Plant Cell Physiol. 2014, 56, 287-298. [CrossRef] [PubMed]

98. Nagashima, Y.; Ma, Z.; Liu, X.; Qian, X.; Zhang, X.; von Schaewen, A.; Koiwa, H. Multiple Quality Control Mechanisms in the ER and TGN Determine Subcellular Dynamics and Salt-Stress Tolerance Function of KORRIGAN1. Plant Cell 2019, $32,470-485$. [CrossRef] [PubMed]

99. Rubilar-Hernandez, C.; Osorio-Navarro, C.; Cabello, F.; Norambuena, L. PI4KIIlbeta Activity Regulates Lateral Root Formation Driven by Endocytic Trafficking to the Vacuole. Plant Physiol. 2019, 181, 112-126. [CrossRef] [PubMed]

100. Agarwal, P.; Dabi, M.; Sapara, K.K.; Joshi, P.S.; Agarwal, P.K. Ectopic Expression of JcWRKY Transcription Factor Confers Salinity Tolerance via Salicylic Acid Signaling. Front. Plant Sci. 2016, 7, 1541. [CrossRef]

101. Ahanger, M.A.; Aziz, U.; Alsahli, A.A.; Alyemeni, M.N.; Ahmad, P. Influence of Exogenous Salicylic Acid and Nitric Oxide on Growth, Photosynthesis, and Ascorbate-Glutathione Cycle in Salt Stressed Vigna angularis. Biomolecules 2019, 10, 42. [CrossRef] 
102. Jayakannan, M.; Bose, J.; Babourina, O.; Shabala, S.; Massart, A.; Poschenrieder, C.; Rengel, Z. The NPR1-dependent salicylic acid signalling pathway is pivotal for enhanced salt and oxidative stress tolerance in Arabidopsis. J. Exp. Bot. 2015, 66, 1865-1875. [CrossRef]

103. Janda, M.; Sasek, V.; Ruelland, E. The Arabidopsis pi4kIIIbeta1beta2 double mutant is salicylic acid-overaccumulating: A new example of salicylic acid influence on plant stature. Plant Signal. Behav. 2014, 9, e977210. [CrossRef] [PubMed]

104. Krinke, O.; Ruelland, E.; Valentová, O.; Vergnolle, C.; Renou, J.-P.; Taconnat, L.; Flemr, M.; Burketová, L.; Zachowski, A. Phosphatidylinositol 4-Kinase Activation Is an Early Response to Salicylic Acid in Arabidopsis Suspension Cells. Plant. Physiol. 2007, 144, 1347-1359. [CrossRef] [PubMed]

105. Šašek, V.; Janda, M.; Delage, E.; Puyaubert, J.; Guivarc'h, A.; López Maseda, E.; Dobrev, P.I.; Caius, J.; Bóka, K.; Valentová, O.; et al. Constitutive salicylic acid accumulation in pi4kIII $\beta 1 \beta 2$ Arabidopsis plants stunts rosette but not root growth. New Phytol. 2014, 203, 805-816. [CrossRef] [PubMed]

106. Antignani, V.; Klocko, A.L.; Bak, G.; Chandrasekaran, S.D.; Dunivin, T.; Nielsen, E. Recruitment of PLANT U-BOX13 and the PI $\beta 1 / \beta 2$ phosphatidylinositol-4 kinases by the small GTPase RabA4B plays important roles during salicylic acid-mediated plant defense signaling in Arabidopsis. Plant Cell 2015, 27, 243-261. [CrossRef] [PubMed]

107. DeWald, D.B.; Torabinejad, J.; Jones, C.A.; Shope, J.C.; Cangelosi, A.R.; Thompson, J.E.; Prestwich, G.D.; Hama, H. Rapid Accumulation of Phosphatidylinositol 4,5-Bisphosphate and Inositol 1,4,5-Trisphosphate Correlates with Calcium Mobilization in Salt-Stressed Arabidopsis. Plant. Physiol. 2001, 126, 759-769. [CrossRef] [PubMed]

108. Ribba, T.; Garrido-Vargas, F.; O'Brien, J.A. Auxin-mediated responses under salt stress: From developmental regulation to biotechnological applications. J. Exp. Bot. 2020, 71, 3843-3853. [CrossRef]

109. Tejos, R.; Sauer, M.; Vanneste, S.; Palacios-Gomez, M.; Li, H.; Heilmann, M.; van Wijk, R.; Vermeer, J.; Heilmann, I.; Munnik, T.; et al. Bipolar Plasma Membrane Distribution of Phosphoinositides and Their Requirement for Auxin-Mediated Cell Polarity and Patterning in Arabidopsis. Plant Cell 2014, 26, 2114-2128. [CrossRef]

110. Ischebeck, T.; Werner, S.; Krishnamoorthy, P.; Lerche, J.; Meijón, M.; Stenzel, I.; Löfke, C.; Wiessner, T.; Im, Y.J.; Perera, I.; et al. Phosphatidylinositol 4,5-Bisphosphate Influences PIN Polarization by Controlling Clathrin-Mediated Membrane Trafficking in Arabidopsis. Plant Cell 2013, 25, 4894-4911. [CrossRef]

111. Mei, Y.; Jia, W.-J.; Chu, Y.-J.; Xue, H.-W. Arabidopsis phosphatidylinositol monophosphate 5-kinase 2 is involved in root gravitropism through regulation of polar auxin transport by affecting the cycling of PIN proteins. Cell Res. 2011, 22, 581-597. [CrossRef]

112. Heilmann, I. Towards understanding the function of stress-inducible PtdIns $(4,5) \mathrm{P}_{2}$ in plants. Commun. Integr. Biol. 2008, 1 , 204-206. [CrossRef]

113. König, S.; Ischebeck, T.; Lerche, J.; Stenzel, I.; Heilmann, I. Salt-stress-induced association of phosphatidylinositol 4,5-bisphosphate with clathrin-coated vesicles in plants. Biochem. J. 2008, 415, 387-399. [CrossRef] [PubMed]

114. Lee, E.; Vanneste, S.; Pérez-Sancho, J.; Benitez-Fuente, F.; Strelau, M.; Macho, A.P.; Botella, M.A.; Friml, J.; Rosado, A. Ionic stress enhances ER-PM connectivity via phosphoinositide-associated SYT1 contact site expansion in Arabidopsis. Proc. Natl. Acad. Sci. USA 2019, 116, 1420-1429. [CrossRef] [PubMed]

115. Kapoor, R.T.; Hasanuzzaman, M. Exogenous kinetin and putrescine synergistically mitigate salt stress in Luffa acutangula by modulating physiology and antioxidant defense. Physiol. Mol. Biol. Plants 2020, 26, 2125-2137. [CrossRef] [PubMed]

116. Li, S.; Jin, H.; Zhang, Q. The Effect of Exogenous Spermidine Concentration on Polyamine Metabolism and Salt Tolerance in Zoysiagrass (Zoysia japonica Steud) Subjected to Short-Term Salinity Stress. Front. Plant Sci. 2016, 7, 1221. [CrossRef]

117. Liu, J.; Yang, R.; Jian, N.; Wei, L.; Ye, L.; Wang, R.; Gao, H.; Zheng, Q. Putrescine metabolism modulates the biphasic effects of brassinosteroids on canola and Arabidopsis salt tolerance. Plant Cell Environ. 2020, 43, 1348-1359. [CrossRef]

118. Liu, L.; Liu, D.; Wang, Z.; Zou, C.; Wang, B.; Zhang, H.; Gai, Z.; Zhang, P.; Wang, Y.; Li, C. Exogenous allantoin improves the salt tolerance of sugar beet by increasing putrescine metabolism and antioxidant activities. Plant. Physiol. Biochem. 2020, 154, 699-713. [CrossRef]

119. Zarza, X.; Van Wijk, R.; Shabala, L.; Hunkeler, A.; Lefebvre, M.; Rodriguez-Villalón, A.; Shabala, S.; Tiburcio, A.F.; Heilmann, I.; Munnik, T. Lipid kinases PIP5K7 and PIP5K9 are required for polyamine-triggered K+efflux in Arabidopsis roots. Plant. J. 2020, 104, 416-432. [CrossRef]

120. Leshem, Y.; Seri, L.; Levine, A. Induction of phosphatidylinositol 3-kinase-mediated endocytosis by salt stress leads to intracellular production of reactive oxygen species and salt tolerance. Plant. J. 2007, 51, 185-197. [CrossRef]

121. Liu, J.; Zhou, J.; Xing, D. Phosphatidylinositol 3-Kinase Plays a Vital Role in Regulation of Rice Seed Vigor via Altering NADPH Oxidase Activity. PLoS ONE 2012, 7, e33817. [CrossRef]

122. Jung, J.-Y.; Kim, Y.-W.; Kwak, J.M.; Hwang, J.-U.; Young, J.; Schroeder, J.; Hwang, I.; Lee, Y. Phosphatidylinositol 3- and 4-Phosphate Are Required for Normal Stomatal Movements. Plant Cell 2002, 14, 2399-2412. [CrossRef]

123. Park, K.-Y.; Jung, J.-Y.; Park, J.; Hwang, J.-U.; Kim, Y.-W.; Hwang, I.; Lee, Y. A Role for Phosphatidylinositol 3-Phosphate in Abscisic Acid-Induced Reactive Oxygen Species Generation in Guard Cells. Plant. Physiol. 2003, 132, 92-98. [CrossRef]

124. Zhang, H.; Liu, X.; Zhang, X.; Qin, N.; Xu, K.; Yin, W.; Zheng, Y.; Song, Y.; Zeng, R.; Liu, J. Phosphoinositide 3-Kinase Promotes Oxidative Burst, Stomatal Closure and Plant Immunity in Bacterial Invasion. Front. Plant Sci. 2020, 10, 1740. [CrossRef]

125. Avin-Wittenberg, T. Autophagy and its role in plant abiotic stress management. Plant Cell Environ. 2019, 42, 1045-1053. [CrossRef] [PubMed] 
126. Qi, H.; Xia, F.-N.; Xiao, S. Autophagy in plants: Physiological roles and post-translational regulation. J. Integr. Plant. Biol. 2021, 63, 161-179. [CrossRef] [PubMed]

127. Liu, Y.; Xiong, Y.; Bassham, D.C. Autophagy is required for tolerance of drought and salt stress in plants. Autophagy 2009, 5, 954-963. [CrossRef] [PubMed]

128. Luo, L.; Zhang, P.; Zhu, R.; Fu, J.; Su, J.; Zheng, J.; Wang, Z.; Wang, D.; Gong, Q. Autophagy Is Rapidly Induced by Salt Stress and Is Required for Salt Tolerance in Arabidopsis. Front. Plant Sci. 2017, 8, 1459. [CrossRef]

129. Zhuang, X.; Wang, H.; Lam, S.K.; Gao, C.; Wang, X.; Cai, Y.; Jiang, L. A BAR-Domain Protein SH3P2, Which Binds to Phosphatidylinositol 3-Phosphate and ATG8, Regulates Autophagosome Formation in Arabidopsis. Plant Cell 2013, 25, 4596-4615. [CrossRef] [PubMed]

130. Dek, M.S.P.; Padmanabhan, P.; Sherif, S.; Subramanian, J.; Paliyath, A.G. Upregulation of Phosphatidylinositol 3-Kinase (PI3K) Enhances Ethylene Biosynthesis and Accelerates Flower Senescence in Transgenic Nicotiana tabacum L. Int. J. Mol. Sci. 2017, 18, 1533. [CrossRef]

131. Villasuso, A.L.; Racagni, G.E.; Machado, E.E. Phosphatidylinositol kinases as regulators of GA-stimulated $\alpha$-amylase secretion in barley (Hordeum vulgare). Physiol. Plant. 2008, 133, 157-166. [CrossRef]

132. Liu, J.; Ji, Y.; Zhou, J.; Xing, D. Phosphatidylinositol 3-Kinase Promotes V-ATPase Activation and Vacuolar Acidification and Delays Methyl Jasmonate-Induced Leaf Senescence. Plant. Physiol. 2016, 170, 1714-1731. [CrossRef]

133. Liu, J.; Zhou, J.; Xing, D. A pivotal role of phosphatidylinositol 3-kinase in delaying of methyl jasmonate-induced leaf senescence. Plant. Signal. Behav. 2016, 11, e1147642. [CrossRef]

134. Delgado, C.; Mora-Poblete, F.; Ahmar, S.; Chen, J.-T.; Figueroa, C. Jasmonates and Plant Salt Stress: Molecular Players, Physiological Effects, and Improving Tolerance by Using Genome-Associated Tools. Int. J. Mol. Sci. 2021, 22, 3082. [CrossRef] [PubMed]

135. Zhao, H.; Yin, C.; Ma, B.; Chen, S.; Zhang, J. Ethylene signaling in rice and Arabidopsis: New regulators and mechanisms. J. Integr. Plant. Biol. 2020, 63, 102-125. [CrossRef] [PubMed]

136. Kim, S.-G.; Park, C.-M. Gibberellic acid-mediated salt signaling in seed germination. Plant. Signal. Behav. 2008, 3, 877-879. [CrossRef]

137. Liu, S.; Zhang, P.; Li, C.; Xia, G. The moss jasmonate ZIM-domain protein PnJAZ1 confers salinity tolerance via crosstalk with the abscisic acid signalling pathway. Plant. Sci. 2018, 280, 1-11. [CrossRef] [PubMed]

138. Leprince, A.-S.; Magalhaes, N.; de Vos, D.; Bordenave, M.; Crilat, E.; Clement, G.; Meyer, C.; Munnik, T.; Savoure, A.; Clément, G.; et al. Involvement of Phosphatidylinositol 3-kinase in the regulation of proline catabolism in Arabidopsis thaliana. Front. Plant Sci. 2015, 5, 772. [CrossRef] [PubMed]

139. Hirano, T.; Munnik, T.; Sato, M.H. Phosphatidylinositol 3-phosphate 5-kinase, FAB1/PIKfyve kinase mediates endosome maturation to establish endosome-cortical microtubule interaction in Arabidopsis. Plant Physiol. 2015, 169, 1961-1974. [CrossRef]

140. Hirano, T.; Sato, M.H. Arabidopsis FAB1A/B is possibly involved in the recycling of auxin transporters. Plant Signal. Behav. 2011, 6, 583-585. [CrossRef]

141. Karali, D.; Oxley, D.; Runions, J.; Ktistakis, N.; Farmaki, T. The Arabidopsis thaliana Immunophilin ROF1 Directly Interacts with $\mathrm{PI}(3) \mathrm{P}$ and $\mathrm{PI}(3,5) \mathrm{P}_{2}$ and Affects Germination under Osmotic Stress. PLoS ONE 2012, 7, e48241. [CrossRef]

142. Deng, X.; Yuan, S.; Cao, H.; Lam, S.M.; Shui, G.; Hong, Y.; Wang, X. Phosphatidylinositol-hydrolyzing phospholipase C4 modulates rice response to salt and drought. Plant Cell Environ. 2018, 42, 536-548. [CrossRef] [PubMed]

143. Singh, A.; Kanwar, P.; Pandey, A.; Tyagi, A.K.; Sopory, S.K.; Kapoor, S.; Pandey, G.K. Comprehensive Genomic Analysis and Expression Profiling of Phospholipase C Gene Family during Abiotic Stresses and Development in Rice. PLoS ONE 2013, 8 , e62494. [CrossRef] [PubMed]

144. Li, L.; Wang, F.; Yan, P.; Jing, W.; Zhang, C.; Kudla, J.; Zhang, W. A phosphoinositide-specific phospholipase C pathway elicits stress-induced Ca $2^{+}$signals and confers salt tolerance to rice. New Phytol. 2017, 214, 1172-1187. [CrossRef] [PubMed]

145. Rodas-Junco, B.; Racagni-Di-Palma, G.; Canul-Chan, M.; Usorach, J.; Hernández-Sotomayor, S. Link between Lipid Second Messengers and Osmotic Stress in Plants. Int. J. Mol. Sci. 2021, 22, 2658. [CrossRef]

146. Sanchez, J.P.; Chua, N.H. Arabidopsis PLC1 is required for secondary responses to abscisic acid signals. Plant Cell 2001, 13, 1143-1154. [CrossRef]

147. Hirayama, T.; Ohto, C.; Mizoguchi, T.; Shinozaki, K. A gene encoding a phosphatidylinositol-specific phospholipase C is induced by dehydration and salt stress in Arabidopsis thaliana. Proc. Natl. Acad. Sci. USA 1995, 92, 3903-3907. [CrossRef]

148. Hunt, L.; Mills, L.N.; Pical, C.; Leckie, C.P.; Aitken, F.L.; Kopka, J.; Mueller-Roeber, B.; McAinsh, M.R.; Hetherington, A.; Gray, J.E. Phospholipase $C$ is required for the control of stomatal aperture by ABA. Plant. J. 2003, 34, 47-55. [CrossRef] [PubMed]

149. Mills, L.N.; Hunt, L.; Leckie, C.P.; Aitken, F.L.; Wentworth, M.; McAinsh, M.R.; Gray, J.E.; Hetherington, A.M. The effects of manipulating phospholipase C on guard cell ABA-signalling. J. Exp. Bot. 2003, 55, 199-204. [CrossRef] [PubMed]

150. Staxén, I.; Pical, C.; Montgomery, L.T.; Gray, J.E.; Hetherington, A.; McAinsh, M.R. Abscisic acid induces oscillations in guard-cell cytosolic free calcium that involve phosphoinositide-specific phospholipase C. Proc. Natl. Acad. Sci. USA 1999, 96, $1779-1784$. [CrossRef]

151. Van Wijk, R.; Zhang, Q.; Zarza, X.; Lamers, M.; Marquez, F.R.; Guardia, A.; Scuffi, D.; García-Mata, C.; Ligterink, W.; Haring, M.A.; et al. Role for Arabidopsis PLC7 in Stomatal Movement, Seed Mucilage Attachment, and Leaf Serration. Front. Plant Sci. 2018, 9, 1721. [CrossRef] [PubMed] 
152. Zhang, Q.; van Wijk, R.; Shahbaz, M.; Roels, W.; Van Schooten, B.; Vermeer, J.; Zarza, X.; Guardia, A.; Scuffi, D.; García-Mata, C.; et al. Arabidopsis Phospholipase C3 is Involved in Lateral Root Initiation and ABA Responses in Seed Germination and Stomatal Closure. Plant Cell Physiol. 2017, 59, 469-486. [CrossRef]

153. Georges, F.; Das, S.; Ray, H.; Bock, C.; Nokhrina, K.; Kolla, V.A.; Keller, W. Over-expression of Brassica napus phosphatidylinositolphospholipase $\mathrm{C} 2$ in canola induces significant changes in gene expression and phytohormone distribution patterns, enhances drought tolerance and promotes early flowering and maturation. Plant Cell Environ. 2009, 32, 1664-1681. [CrossRef]

154. Chen, X.; Li, L.; Xu, B.; Zhao, S.; Lu, P.; He, Y.; Ye, T.; Feng, Y.-Q.; Wu, Y. Phosphatidylinositol-specific phospholipase C2 functions in auxin-modulated root development. Plant Cell Environ. 2018, 42, 1441-1457. [CrossRef] [PubMed]

155. Zhang, Q.; van Wijk, R.; Zarza, X.; Shahbaz, M.; Van Hooren, M.; Guardia, A.; Scuffi, D.; García-Mata, C.; Ende, W.V.D.; Hoffmann-Benning, S.; et al. Knock-Down of Arabidopsis PLC5 Reduces Primary Root Growth and Secondary Root Formation While Overexpression Improves Drought Tolerance and Causes Stunted Root Hair Growth. Plant Cell Physiol. 2018, 59, $2004-2019$. [CrossRef] [PubMed]

156. Kanehara, K.; Yu, C.-Y.; Cho, Y.; Cheong, W.-F.; Torta, F.; Shui, G.; Wenk, M.R.; Nakamura, Y. Arabidopsis AtPLC2 Is a Primary Phosphoinositide-Specific Phospholipase C in Phosphoinositide Metabolism and the Endoplasmic Reticulum Stress Response. PLoS Genet. 2015, 11, e1005511. [CrossRef]

157. Parre, E.; Ghars, M.A.; Leprince, A.-S.; Thiery, L.; Lefebvre, D.; Bordenave, M.; Richard, L.; Mazars, C.; Abdelly, C.; Savouré, A. Calcium Signaling via Phospholipase C Is Essential for Proline Accumulation upon Ionic but Not Nonionic Hyperosmotic Stresses in Arabidopsis. Plant. Physiol. 2007, 144, 503-512. [CrossRef] [PubMed]

158. Djafi, N.; Vergnolle, C.; Cantrel, C.; Wietrzyñski, W.; Delage, E.; Cochet, F.; Puyaubert, J.; Soubigou-Taconnat, L.; Gey, D.; Collin, S.; et al. The Arabidopsis DREB2 genetic pathway is constitutively repressed by basal phosphoinositide-dependent phospholipase C coupled to diacylglycerol kinase. Front. Plant Sci. 2013, 4, 307. [CrossRef]

159. Hong, Y.; Zhao, J.; Guo, L.; Kim, S.-C.; Deng, X.; Wang, G.; Zhang, G.; Li, M.; Wang, X. Plant phospholipases D and C and their diverse functions in stress responses. Prog. Lipid Res. 2016, 62, 55-74. [CrossRef]

160. Yamaoka, Y.; Yu, Y.; Mizoi, J.; Fujiki, Y.; Saito, K.; Nishijima, M.; Lee, Y.; Nishida, I. Phosphatidylserine synthase1 is required for microspore development in Arabidopsis thaliana. Plant. J. 2011, 67, 648-661. [CrossRef]

161. Lv, S.; Tai, F.; Guo, J.; Jiang, P.; Lin, K.; Wang, D.; Zhang, X.; Li, Y. Phosphatidylserine Synthase from Salicornia europaea Is Involved in Plant Salt Tolerance by Regulating Plasma Membrane Stability. Plant Cell Physiol. 2020, 62, 66-79. [CrossRef]

162. Yu, Y.; Kou, M.; Gao, Z.; Liu, Y.; Xuan, Y.; Liu, Y.; Tang, Z.; Cao, Q.; Li, Z.; Sun, J. Involvement of Phosphatidylserine and Triacylglycerol in the Response of Sweet Potato Leaves to Salt Stress. Front. Plant Sci. 2019, 10, 1086. [CrossRef] [PubMed]

163. Yu, Y.; Xuan, Y.; Bian, X.; Zhang, L.; Pan, Z.; Kou, M.; Cao, Q.; Tang, Z.; Li, Q.; Ma, D.; et al. Overexpression of phosphatidylserine synthase IbPSS1 affords cellular $\mathrm{Na}^{+}$homeostasis and salt tolerance by activating plasma membrane $\mathrm{Na}^{+} / \mathrm{H}^{+}$antiport activity in sweet potato roots. Hortic. Res. 2020, 7, 131. [CrossRef] [PubMed]

164. Platre, M.P.; Noack, L.; Doumane, M.; Bayle, V.; Simon, M.L.A.; Maneta-Peyret, L.; Fouillen, L.; Stanislas, T.; Armengot, L.; Pejchar, P.; et al. A Combinatorial Lipid Code Shapes the Electrostatic Landscape of Plant Endomembranes. Dev. Cell 2018, 45, 465-480.e11. [CrossRef] [PubMed]

165. Platre, M.P.; Bayle, V.; Armengot, L.; Bareille, J.; Marquès-Bueno, M.D.M.; Creff, A.; Maneta-Peyret, L.; Fiche, J.-B.; Nollmann, M.; Miège, C.; et al. Developmental control of plant Rho GTPase nano-organization by the lipid phosphatidylserine. Science 2019, 364 57-62. [CrossRef]

166. Li, C.; Lu, H.; Li, W.; Yuan, M.; Fu, Y. A ROP2-RIC1 pathway fine-tunes microtubule reorganization for salt tolerance in Arabidopsis. Plant Cell Environ. 2017, 40, 1127-1142. [CrossRef] [PubMed]

167. Chen, W.; Taylor, M.C.; Barrow, R.A.; Croyal, M.; Masle, J. Loss of Phosphoethanolamine N-Methyltransferases Abolishes Phosphatidylcholine Synthesis and Is Lethal. Plant. Physiol. 2018, 179, 124-142. [CrossRef]

168. Omoto, E.; Iwasaki, Y.; Miyake, H.; Taniguchi, M. Salinity induces membrane structure and lipid changes in maize mesophyll and bundle sheath chloroplasts. Physiol. Plant. 2015, 157, 13-23. [CrossRef]

169. Pical, C.; Westergren, T.; Dove, S.K.; Larsson, C.; Sommarin, M. Salinity and Hyperosmotic Stress Induce Rapid Increases in Phosphatidylinositol 4,5-Bisphosphate, Diacylglycerol Pyrophosphate, and Phosphatidylcholine in Arabidopsis thaliana Cells. J. Biol. Chem. 1999, 274, 38232-38240. [CrossRef]

170. Tasseva, G.; Richard, L.; Zachowski, A. Regulation of phosphatidylcholine biosynthesis under salt stress involves choline kinases in Arabidopsis thaliana. FEBS Lett. 2004, 566, 115-120. [CrossRef]

171. Qiao, K.; Wang, M.; Takano, T.; Liu, S. Overexpression of acyl-CoA-binding protein 1 (ChACBP1) from saline-alkali-tolerant Chlorella sp. enhances stress tolerance in Arabidopsis. Front. Plant Sci. 2018, 9, 1772. [CrossRef]

172. Xu, X.; Zhang, J.; Yan, B.; Wei, Y.; Ge, S.; Li, J.; Han, Y.; Li, Z.; Zhao, C.; Xu, J. The Adjustment of Membrane Lipid Metabolism Pathways in Maize Roots Under Saline-Alkaline Stress. Front. Plant Sci. 2021, 12, 635327. [CrossRef]

173. Caldo, K.M.P.; Xu, Y.; Falarz, L.; Jayawardhane, K.; Acedo, J.; Chen, G. Arabidopsis CTP:phosphocholine cytidylyltransferase 1 is phosphorylated and inhibited by sucrose nonfermenting 1-related protein kinase 1 (SnRK1). J. Biol. Chem. 2019, 294, 15862-15874. [CrossRef]

174. Lin, Y.; Kanehara, K.; Nakamura, Y. Arabidopsis CHOLINE/ETHANOLAMINE KINASE 1 (CEK1) is a primary choline kinase localized at the endoplasmic reticulum (ER) and involved in ER stress tolerance. New Phytol. 2019, 223, 1904-1917. [CrossRef] 
175. Yu, C.-Y.; Nguyen, V.C.; Chuang, L.; Kanehara, K. Membrane glycerolipid equilibrium under endoplasmic reticulum stress in Arabidopsis thaliana. Biochem. Biophys. Res. Commun. 2018, 500, 103-109. [CrossRef] [PubMed]

176. Kocourková, D.; Krčková, Z.; Pejchar, P.; Veselková, S.; Valentová, O.; Wimalasekera, R.; Scherer, G.F.E.; Martinec, J. The phosphatidylcholine-hydrolysing phospholipase C NPC4 plays a role in response of Arabidopsis roots to salt stress. J. Exp. Bot. 2011, 62, 3753-3763. [CrossRef] [PubMed]

177. Peters, C.; Li, M.; Narasimhan, R.; Roth, M.; Welti, R.; Wang, X. Nonspecific Phospholipase C NPC4 Promotes Responses to Abscisic Acid and Tolerance to Hyperosmotic Stress in Arabidopsis. Plant Cell 2010, 22, 2642-2659. [CrossRef] [PubMed]

178. Gao, Y.; Li, M.; Zhang, X.; Yang, Q.; Huang, B. Up-regulation of lipid metabolism and glycine betaine synthesis are associated with choline-induced salt tolerance in halophytic seashore paspalum. Plant Cell Environ. 2019, 43, 159-173. [CrossRef]

179. Summers, P.S.; Weretilnyk, E.A. Choline Synthesis in Spinach in Relation to Salt Stress. Plant. Physiol. 1993, 103, 1269-1276. [CrossRef]

180. Zhang, K.; Lyu, W.; Gao, Y.; Zhang, X.; Sun, Y.; Huang, B. Choline-Mediated Lipid Reprogramming as a Dominant Salt Tolerance Mechanism in Grass Species Lacking Glycine Betaine. Plant Cell Physiol. 2020, 61, 2018-2030. [CrossRef]

181. Xu, C.; Härtel, H.; Wada, H.; Hagio, M.; Yu, B.; Eakin, C.; Benning, C. The pgp1 Mutant Locus of Arabidopsis Encodes a Phosphatidylglycerolphosphate Synthase with Impaired Activity. Plant. Physiol. 2002, 129, 594-604. [CrossRef]

182. Frentzen, M. Phosphatidylglycerol and sulfoquinovosyldiacylglycerol: Anionic membrane lipids and phosphate regulation. Curr. Opin. Plant. Biol. 2004, 7, 270-276. [CrossRef]

183. Han, X.; Shi, Y.; Liu, G.; Guo, Y.; Yang, Y. Activation of ROP6 GTPase by Phosphatidylglycerol in Arabidopsis. Front. Plant Sci. 2018, 9, 347. [CrossRef]

184. Kobayashi, K.; Endo, K.; Wada, H. Multiple Impacts of Loss of Plastidic Phosphatidylglycerol Biosynthesis on Photosynthesis during Seedling Growth of Arabidopsis. Front. Plant Sci. 2016, 7, 336. [CrossRef] [PubMed]

185. Liu, N.-J.; Wang, N.; Bao, J.-J.; Zhu, H.-X.; Wang, L.-J.; Chen, X.-Y. Lipidomic Analysis Reveals the Importance of GIPCs in Arabidopsis Leaf Extracellular Vesicles. Mol. Plant. 2020, 13, 1523-1532. [CrossRef] [PubMed]

186. Han, X.; Yang, Y.; Zhao, F.; Zhang, T.; Yu, X. An improved protein lipid overlay assay for studying lipid-protein interactions. Plant Methods 2020, 16, 1-11. [CrossRef]

187. Hirano, T.; Stecker, K.; Munnik, T.; Xu, H.; Sato, M.H. Visualization of Phosphatidylinositol 3,5-Bisphosphate Dynamics by a Tandem ML1N-Based Fluorescent Protein Probe in Arabidopsis. Plant Cell Physiol. 2017, 58, 1185-1195. [CrossRef] [PubMed]

188. Vermeer, J.; Thole, J.M.; Goedhart, J.; Nielsen, E.; Munnik, T.; Gadella, T.W., Jr. Imaging phosphatidylinositol 4-phosphate dynamics in living plant cells. Plant. J. 2009, 57, 356-372. [CrossRef]

189. Vermeer, J.E.; van Leeuwen, W.; Tobena-Santamaria, R.; Laxalt, A.M.; Jones, D.R.; Divecha, N.; Gadella, T.W., Jr.; Munnik, T. Visualization of PtdIns3P dynamics in living plant cells. Plant J. 2006, 47, 687-700. [CrossRef]

190. Vermeer, J.E.M.; Munnik, T. Imaging lipids in living plants. In Lipid Signaling in Plants; Munnik, T., Ed.; Springer: Berlin/Heidelberg, Germany, 2010; pp. 185-199.

191. Vermeer, J.; van Wijk, R.; Goedhart, J.; Geldner, N.; Chory, J.; Gadella, T.; Munnik, T. In Vivo Imaging of Diacylglycerol at the Cytoplasmic Leaflet of Plant Membranes. Plant Cell Physiol. 2017, 58, 1196-1207. [CrossRef]

192. De Jong, F.; Munnik, T. Attracted to membranes: Lipid-binding domains in plants. Plant Physiol. 2021, 185, 707-723. [CrossRef]

193. Poyton, M.F.; Pullanchery, S.; Sun, S.; Yang, T.; Cremer, P.S. Zn2+ Binds to Phosphatidylserine and Induces Membrane Blebbing. J. Am. Chem. Soc. 2020, 142, 18679-18686. [CrossRef]

194. Xu, J.; Chen, D.; Yan, X.; Chen, J.; Zhou, C. Global characterization of the photosynthetic glycerolipids from a marine diatom Stephanodiscus sp. by ultra performance liquid chromatography coupled with electrospray ionization-quadrupole-time of flight mass spectrometry. Anal. Chim. Acta 2010, 663, 60-68. [CrossRef]

195. Diehl, B.W.; Herling, H.; Riedl, I.; Heinz, E. 13C-NMR analysis of the positional distribution of fatty acids in plant glycolipids. Chem. Phys. Lipids 1995, 77, 147-153. [CrossRef]

196. Murakami, Y.; Tsuyama, M.; Kobayashi, Y.; Kodama, H.; Iba, K. Trienoic Fatty Acids and Plant Tolerance of High Temperature. Science 2000, 287, 476-479. [CrossRef] [PubMed]

197. Adachi, Y.; Itoh, K.; Yamada, T.; Cerveny, K.L.; Suzuki, T.L.; Macdonald, P.; Frohman, M.A.; Ramachandran, R.; Iijima, M.; Sesaki, H. Coincident Phosphatidic Acid Interaction Restrains Drp1 in Mitochondrial Division. Mol. Cell 2016, 63, 1034-1043. [CrossRef] [PubMed]

198. König, S.; Mosblech, A.; Heilmann, I. Stress-inducible and constitutive phosphoinositide pools have distinctive fatty acid patterns in Arabidopsis thaliana. FASEB J. 2007, 21, 1958-1967. [CrossRef] 